Review

\title{
Activation of the DNA Damage Response by RNA Viruses
}

\author{
Ellis L. Ryan, Robert Hollingworth and Roger J. Grand * \\ Received: 28 September 2015; Accepted: 24 November 2015; Published: 6 January 2016 \\ Academic Editor: Wolf-Dietrich Heyer \\ School of Cancer Sciences, College of Medicine and Dentistry, University of Birmingham, Birmingham B15 2TT, \\ UK; exr729@student.bham.ac.uk (E.L.R.); rxh291@student.bham.ac.uk (R.H.) \\ * Correspondence: r.j.a.grand@bham.ac.uk; Tel.: +44-121-414-2805; Fax: +44-121-414-4486
}

\begin{abstract}
RNA viruses are a genetically diverse group of pathogens that are responsible for some of the most prevalent and lethal human diseases. Numerous viruses introduce DNA damage and genetic instability in host cells during their lifecycles and some species also manipulate components of the DNA damage response (DDR), a complex and sophisticated series of cellular pathways that have evolved to detect and repair DNA lesions. Activation and manipulation of the DDR by DNA viruses has been extensively studied. It is apparent, however, that many RNA viruses can also induce significant DNA damage, even in cases where viral replication takes place exclusively in the cytoplasm. DNA damage can contribute to the pathogenesis of RNA viruses through the triggering of apoptosis, stimulation of inflammatory immune responses and the introduction of deleterious mutations that can increase the risk of tumorigenesis. In addition, activation of DDR pathways can contribute positively to replication of viral RNA genomes. Elucidation of the interactions between RNA viruses and the DDR has provided important insights into modulation of host cell functions by these pathogens. This review summarises the current literature regarding activation and manipulation of the DDR by several medically important RNA viruses.
\end{abstract}

Keywords: RNA viruses; retroviruses; DNA damage response; HIV-1; HTLV-1; HCV; Influenza A; IBV

\section{RNA Viruses}

Viruses that use RNA as their genetic material are a diverse group of obligate parasites associated with some of the most infectious and deadly human diseases. The genomes of RNA viruses are highly varied and can be either double-stranded or single-stranded, with the latter being of negative or positive polarity. RNA virus genomes can also be either segmented, whereby each segment typically encodes one viral protein, or unimolecular, in which a single polyprotein is translated and cleaved to form individual viral proteins [1]. The genetic diversity of RNA viruses stems from a high rate of spontaneous mutation and has made development of antiviral therapies and vaccines extremely challenging [2]. The increased mutation frequency is primarily due to a lack of proofreading by the RNA-dependent RNA polymerases (RdRp) required for replication of many RNA viruses [3]. This elevated mutation rate is believed to be the reason that RNA virus genomes are usually restricted to lengths of less than $30 \mathrm{~Kb}$ and therefore tend to be smaller and encode fewer proteins than those of many DNA viruses [4].

RNA viruses have diverse modes of replication that largely depend on their genome configuration. In positive-sense single-stranded RNA viruses, such as coronaviruses and hepatitis $C$ virus (HCV), the viral genome functions as mRNA and can be directly translated into a viral polyprotein by a host ribosome. Viral proteins can then form membrane-associated replication complexes (RC) in the cytoplasm that provide sites for viral RNA synthesis [5]. Negative-strand RNA viruses, such as Rabies 
and Influenza, must initially use a viral RdRp to produce monocistronic mRNAs. These mRNAs are translated to produce viral proteins while production of new viral genomes first requires synthesis of positive-sense RNA which is then converted to negative-sense viral genomes. In this case, virus replication and assembly requires formation of ribonucleoprotein (RNP) complexes that contain viral polymerases and nucleoproteins [6].

Retroviruses are a unique class of RNA viruses whose lifecycles contain a DNA intermediate that requires integration into the host cell genome prior to viral gene expression. The retrovirus genome consists of two identical positive-strand RNA molecules of between 7 and $12 \mathrm{~kb}$ that are capped at the $5^{\prime}$ end and polyadenylated at the 3' end [7]. Following cell entry, viral reverse transcriptase (RT) enzymes are used to generate double-stranded DNA (dsDNA) molecules from the RNA templates. These are then transported to the nucleus and integrated into cellular DNA which requires another virus-encoded enzyme known as integrase (IN) [8]. The viral mRNA is exported to the cytoplasm where it is translated to viral proteins and the remainder is packaged as new viral genomes. Since integration of the viral cDNA requires breaks in cellular DNA, activation of host DNA repair pathways is a consequence of retroviral infection that is discussed in detail below.

For some RNA viruses, such as members of the families Orthomyxoviridae and Retroviridae, at least part of the replication cycle takes place in the nucleus. For the majority, however, replication occurs exclusively in the cytoplasm and therefore the impact of the viral lifecycle on the nucleus may be less severe than is the case for many DNA viruses. However, proteins encoded by RNA viruses are often transported to the nucleus where they can perturb cellular functions and inhibit the antiviral response [9]. As is discussed below, these nuclear activities may involve the direct or indirect introduction of DNA damage and impairment of the subsequent cellular response.

\section{The Cellular DNA Damage Response and DNA Repair Pathways}

The integrity of the genome is under constant attack from agents able to damage DNA. DNA damage can be generated from both endogenous cellular processes and exogenous agents, and it has been estimated that cells accumulate tens of thousands of lesions per cell per day [10]. Endogenous cellular processes that cause DNA damage include the generation of reactive oxygen species (ROS) that generate base damage, DNA polymerase errors during replication that can cause DNA mismatches and the abortive action of enzymes, such as DNA topoisomerase I (TOPI) and DNA topoisomerase II (TOPII) that can lead to DNA strand breaks [11]. Exogenous agents such as ultra-violet (UV) radiation and ionising radiation (IR), as well as infection with a range of microorganisms, can also result in significant DNA damage [12].

The rapid and accurate repair of DNA lesions is vital for cellular survival and for the maintenance of genome stability. If not accurately repaired, DNA damage can cause erroneous changes in the genetic code leading to increased mutational load and an elevated risk of developing cancer [10]. To respond to genotoxic lesions induced by DNA damaging agents, cells have evolved complex mechanisms for DNA damage detection and repair, collectively termed the DNA damage response (DDR). The DDR pathways comprise a highly coordinated network of proteins which are rapidly activated in the presence of DNA damage. The DDR is composed of sensors, transducers and effectors, which together form a signalling cascade involving complex interactions and post-translational modifications (Figure 1). Initiation of this cascade leads to cell cycle arrest and the activation of DNA repair pathways. The DDR is principally mediated by the PI3K kinase family: ataxia telangiectasia mutated (ATM), ATM and Rad3-related (ATR) and DNA-dependent protein kinase (DNA-PK), and by members of the poly (ADP-ribose) polymerase (PARP) family. ATM and DNA-PK are primarily activated by double-strand breaks (DSBs); whilst ATR is stimulated at regions of single-stranded DNA (ssDNA) generated at DSBs or stalled replication forks [13]. PARP1 is primarily involved in the detection and repair of single-strand breaks (SSBs) [14]. 


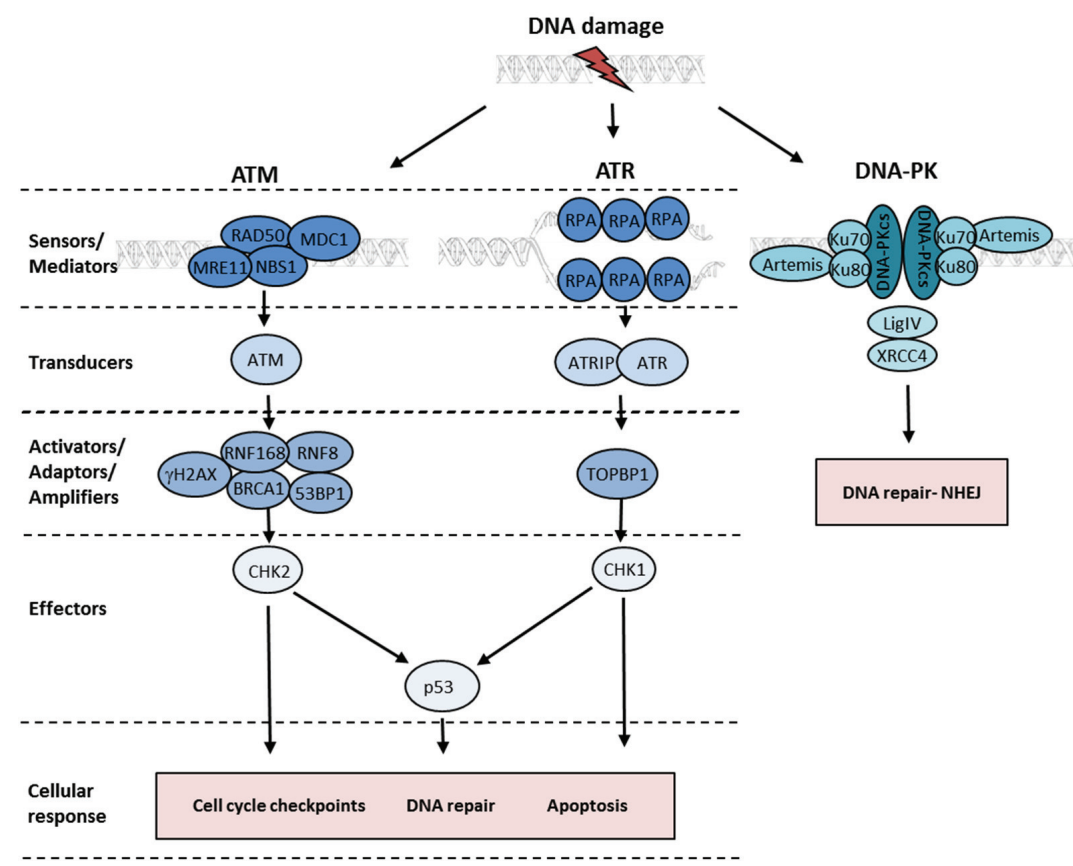

Figure 1. ATM, ATR and DNA-PK signalling pathways. The DNA damage signalling pathways are primarily mediated by the ATM, ATR and DNA-PK kinases. DSBs are detected by the MRN complex (MRE11, RAD50 and NBS1) which recruits and activates ATM at the site of the break. Activated ATM phosphorylates numerous effector proteins such as CHK2 and p53. Phosphorylation of the histone variant H2AX by ATM and ubiquitination of H2AX by RNF8 and RNF168 E3 ubiquitin ligases precedes recruitment of repair proteins such as BRCA1 and 53BP1. ATR is primarily activated at regions of ssDNA which are first coated by RPA. ATR is then recruited to RPA-coated ssDNA via its interacting protein ATRIP. The recruitment of TOPBP1 to the ssDNA region is responsible for the activation of ATR which subsequently phosphorylates effector proteins such as $\mathrm{CHK} 1$ and p53. In contrast to the ATM and ATR kinases, DNA-PK is responsible for the regulation of the NHEJ DSB repair pathway. Image adapted from [15].

\section{The ATM Kinase and the Detection of Double-Strand Breaks}

DSBs are discontinuities in both strands of the DNA double-helix and it is thought that a single cell can accumulate up to 10 endogenously-induced DSBs per day [16]. An early event following DSB formation is the detection of the break by the DSB sensor complex, MRE11-RAD50-NBS1 (MRN). The MRN complex recruits and activates the transducer kinase ATM at the site of the break [17,18]. Active ATM is then able to phosphorylate downstream effector proteins of the DDR including histone H2AX as well as cell cycle checkpoint proteins p53 and CHK2, which promote cell cycle arrest to prevent replication of damaged DNA [19]. Phosphorylated $\mathrm{H} 2 \mathrm{AX}$, referred to as $\gamma \mathrm{H} 2 \mathrm{AX}$, allows binding of the mediator of DNA damage checkpoint 1 (MDC1) at the break, where it is subsequently phosphorylated by ATM [20]. Ubiquitination of histones H2A and H2AX by the E3 ubiquitin ligases RNF8 and RNF168 precedes the recruitment of a range of DNA repair proteins including breast cancer type 1 susceptibility protein (BRCA1) and p53-binding protein 1 (53BP1) [21,22].

\section{ATR Kinase Activation at Single-Stranded DNA}

ATR is activated in response to numerous types of DNA damage that result in the formation of ssDNA [23]. Regions of ssDNA are rapidly coated by replication protein A (RPA), which recruits the transducer protein ATR to the site of the lesion via its interaction with ATR-interacting protein (ATRIP) [23]. A series of protein complexes (the Rad17-replication factor C 2 (RFC2) clamp loader complex and the Rad9-Rad1-Hus1 (9-1-1 complex) are consecutively recruited to the ssDNA-RPA 
complex, ultimately resulting in the localisation of topoisomerase II binding protein 1 (TOPBP1). TOPBP1 is able to activate ATR via interactions with ATRIP and Rad9 of the 9-1-1 complex [24]. This leads to the phosphorylation and subsequent activation of downstream effector proteins, such as p53 and CHK1, which induce cell cycle arrest and DNA repair [19].

\section{The DDR and Cell Cycle Checkpoints}

One of the primary functions of the DDR is to initiate cell cycle arrest following detection of DNA damage, thus preventing the replication of mutated DNA [25]. Three major cell cycle checkpoints have been defined: the G1/S checkpoint is activated to stop the initiation of replication in the event of DNA damage, the intra S-phase checkpoint can be activated in response to replication stress and slows DNA synthesis, and the G2/M checkpoint which ensures that damaged chromosomes are not segregated to the daughter cells during mitosis. Activation of these checkpoints following DNA damage depends on the activities of the kinases ATM, ATR, CHK1 and CHK2.

Activated CHK1 and CHK2 can rapidly activate the G1/S checkpoint by phosphorylating and inactivating the phosphatase Cdc25A which prevents the activation of the Cyclin E-Cdk2 complex thereby inhibiting S-phase entry [26]. CHK1 and CHK2 can also maintain G1/S arrest through phosphorylation and stabilisation of p53. Activated p53 can increase the expression of p21 which inhibits Cyclin E-Cdk2 activity [27]. The intra S-phase checkpoint can also be activated through phosphorylation of Cdc25A resulting in the prevention of Cdc45 loading and firing of replication origins [28]. In addition, ATM can also signal through an alternative pathway during S-phase requiring the MRN complex and phosphorylation of structure maintenance of chromosome 1 (SMC1) [29]. CHK1 and CHK2 can initiate G2/M arrest by inhibiting activation of the cyclin B-Cdk1 complex via phosphorylation and degradation of Cdc25C [30]. The stabilisation of Wee1 following DNA damage acts to maintain G2 arrest through increased phosphorylation of Cdk1 [31].

\section{Double-Strand Break Repair}

The two main DSB repair mechanisms are non-homologous end joining (NHEJ) and homologous recombination (HR) repair. NHEJ involves a coordinated network of proteins which facilitate rapid repair during all stages of the cell cycle. During NHEJ, the DSB is first recognised by the Ku70/80 heterodimer, which forms a ring-like structure around either end of the DSB. Association of Ku70/80 leads to recruitment of the catalytic subunit of the DNA-PK (DNA-PKcs) to form the DNA-PK holoenzyme [32]. Before DNA ends can be re-ligated, they must be restored to their conventional 3' $\mathrm{OH}$ and 5'P termini by end-processing enzymes such as Artemis. DNA ligase IV, in complex with XRCC4 and XLF, performs DNA end-joining of the DSB termini, completing NHEJ [33-35]. Occasionally, NHEJ can result in the loss of nucleotides leading to inaccurate repair. In addition, DNA ends from other regions of the genome can be erroneously re-ligated, resulting in rearrangements and chromosomal translocations [36].

In contrast to NHEJ, HR occurs exclusively during S and G2 phases of the cell cycle and uses the undamaged homologous sister chromatid as a template for accurate repair. The DSB is first processed by endonucleases to produce a 3' overhang which is coated by RPA. RPA is then displaced by the recombinase RAD51 to form a nucleoprotein filament that invades the undamaged strand of the homologous sister chromatid forming a displacement loop (D-loop) [37]. The nucleoprotein filament searches for the undamaged sister chromatid which is used as a template for filling in the missing information on the damaged strand. HR can result in branched structures known as Holliday junctions that must be resolved by endonucleases to restore the two separate strands [38].

\section{Repair of Single-Strand DNA Damage}

Most commonly occurring DNA lesions affect only a single DNA strand and include SSBs, modifications to individual nitrogenous bases and replication errors that introduce mismatched nucleotides [39]. Mechanisms that correct single-strand damage can utilise the undamaged DNA 
strand as a template to ensure accurate repair. Although SSBs are less genotoxic than DSBs, their rapid repair is critical to the maintenance of genome integrity since they can collapse into DSBs if met by a replication fork during DNA replication. Multiple DNA repair pathways have been identified that correct single-strand damage.

Base excision repair (BER) corrects damage to single mismatched or modified bases and is the principle pathway used for the reversal of oxidative DNA damage [40]. During BER, base damage is detected by DNA glycosylases that excise the damaged base creating an apurinic-apyrimidinic (AP) site [41]. The AP endonuclease 1 (APE1) incises the AP site, generating a single-stranded nick [42]. DNA polymerases fill the damaged region which is then sealed by either DNA ligase I or ligase IV [43].

Nucleotide excision repair (NER) is responsible for the removal of helix-distorting, bulky lesions, such as cyclobutane pyrimidine dimers (CPDs) and (6-4) photoproducts, that can be induced by UV radiation [44]. In NER, recognition of the damaged region is followed by excision of the bulky lesion by ERCC1-XPF and XPG endonucleases [45]. Gap filling is carried out by the DNA polymerases Pol $\delta$ and Pol $\varepsilon$ in conjunction with PCNA and ligation by the ligase III-XRCC1 complex [46,47].

DNA base mismatching that occurs due to DNA polymerase errors can be repaired by members of the mismatch repair (MMR) pathway which acts exclusively on the newly synthesised DNA strand. Following detection of mismatched bases by MSH2-MSH6 (MutS $\alpha$ ) or MSH2-MSH3 (MutS $\beta$ ) complexes, the MLH1/PMS2 (MutL $\alpha$ ) complex is then recruited followed by the exonuclease EXO1 which resects the damaged strand [48-51]. The DNA polymerase Pol $\delta$ fills the gap in an RFC and PCNA-dependent manner while DNA ligase I ligates the newly synthesised strand [52,53].

\section{DNA Damage and Apoptosis}

Extensive DNA damage that cannot be repaired can lead to activation of apoptotic pathways and this response represents a crucial barrier against malignant transformation [54]. Increased p53 transcriptional activity following phosphorylation by DDR kinases induces expression of pro-apoptotic proteins such as Bax, Noxa and Puma that trigger cell death via regulation of mitochondrial permeability [55]. Apoptotic pathways can also be activated in response to RNA virus infection as part of the innate and adaptive immune responses to invading pathogens, although some viruses take advantage of apoptotic machinery to aid viral maturation and dissemination. Regardless of the impact on the viral lifecycle, apoptosis can contribute significantly to viral pathogenesis. For example, the human immunodeficiency virus 1 (HIV-1) Vpr protein can promote apoptosis by targeting the mitochondrial permeability transition pore complex and this may contribute to depletion of CD4+ lymphocytes in vivo [56]. In addition, apoptosis induced by the Influenza A virus NS1 protein contributes to lung tissue destruction and widespread cell death and may cause further damage through aberrant inflammatory responses [57].

Since apoptosis occurring prior to production of infectious progeny will have a detrimental effect on viral propagation, RNA viruses have also evolved mechanisms to inhibit or delay the process. The HCV NS3-4A protease contributes to viral immune evasion by cleaving the TRIF component of the Toll-like receptor signalling pathway that could otherwise trigger cell death following recognition of viral RNA [58]. HCV core protein can also promote cellular survival by activation the NF- $\mathrm{kB}$ pathway and this could contribute to the oncogenic potential of the virus [59]. In viruses that induce DNA damage early in their lifecycles, impairment of downstream signalling to apoptotic machinery is often necessary to ensure successful completion of viral replication.

\section{Non-Coding RNAs and the DDR}

It is now apparent that a number of small non-coding RNA (ncRNAs) molecules have important roles in regulation of the DDR. These include microRNAs (miRNAs) that can inhibit gene expression by binding to, and promoting degradation of, messenger RNAs (mRNAs). The miR-34 family of miRNAs, for example, are transcriptional targets of p53 following DDR activation and create a positive feedback loop by repressing expression of HDM4, a negative regulator of p53 [60]. The importance 
of miRNAs in the DDR is also highlighted by the fact that depletion of miRNA processing proteins such as DICER and AGO2 inhibits repair of damaged DNA [61]. An additional set of RNAs that have been reported to play a significant role in the DDR are known as DROSHA- and DICER-dependent small RNAs (DDRNAs) [62,63]. They are transcribed from DNA sequences close to the site of damage and have important roles in the formation of the protein aggregations known as DNA damage foci. A variety of possible roles for the DDRNAs have been proposed, including acting as templates for DNA polymerase, as guides for the recruitment of repair proteins or as scaffolds for the repair foci themselves [64]. Long non-coding RNAs (LncRNAs), RNAs of more than 200 nucleotides in length, are also expressed following DNA damage. It has recently been shown that the IncRNA, DDSR1, regulates levels of BRCA1 and RAP80 at sites of DSBs as well as interacting with BRCA1 and hnRNPUL1, an RNA binding protein with a role in DNA end resection [65].

\section{Viral Interaction with the DDR}

Many viruses are known to cause activation of the DDR during their lifecycles. This may occur as an indirect consequence of cellular stress caused by viral infection or as part of an antiviral response that aims to deactivate the invading viral genomes. In addition, viral DNA may be recognised as damaged cellular DNA while many viral proteins have been shown to cause DNA lesions directly. The DDR may have either beneficial or detrimental effects for the virus, enhancing or inhibiting viral replication. When activation of the DDR is deleterious, viruses may deactivate particular pathways while still making use of certain other elements. For example, adenovirus genomes are joined end to end to form concatemers by the host cell DDR following infection with various disabled viruses [66]. However, the wild type virus is able to hi-jack cellular ubiquitin E3 ligases to target significant DDR proteins for rapid proteasome-mediated degradation [67]. Despite this, several DDR factors are recruited to adenovirus replication centres where they are involved in viral DNA synthesis [68-70]. Other viruses, whilst activating the DDR, make more obvious use of its components. For example, optimal production of progeny simian virus 40 (SV40) requires phosphorylation of large $\mathrm{T}$ antigen by the ATM kinase [71,72]. On the other hand, SV40 also initiates degradation of MRE11, a protein involved in detecting DSBs [73,74]. The larger DNA viruses, such as members of the Gammaherpesvirinae family, have a similarly intricate relationship with the DDR. Epstein-Barr virus (EBV), for example, induces genome instability and DDR activation through the action of a number of viral proteins including EBNA-1 and LMP-1 [75-78]. However, other EBV proteins, such as EBNA3C, can attenuate downstream DDR signalling that could have a negative impact on the viral lifecycle $[79,80]$.

The complex relationship between DNA viruses and the DDR has been summarised in several recent literature reviews $[15,81,82]$. Other published reviews have focused on specific aspects of these interactions, such as the effect on the cell cycle and ubiquitination, $[83,84]$ or on particular viruses in isolation [85-87]. The literature relevant to RNA viruses and the DDR is much more limited and has so far focused on HCV and the retroviruses HIV-1 and human T-cell lymphotropic virus 1 (HTLV-1) [88-91].

\section{RNA Viruses and DNA Damage}

The following text will examine the introduction of DNA damage following infection with RNA viruses as well as considering the subsequent activation and modulation of host DDR pathways. Examples include those from both true RNA viruses, which mostly replicate in the cytoplasm, and retroviruses, whose lifecycle includes a DNA intermediate that integrates into the host cell genome. A summary of interactions between several RNA viruses and the DDR is also presented in Table 1. 
Table 1. Overview of several RNA viruses which impact on the cellular DDR.

\begin{tabular}{|c|c|c|c|c|}
\hline Virus & Family & RNA Genome Conformation & DDR Consequences & Representative References \\
\hline $\begin{array}{l}\text { Human immunodeficiency } \\
\text { Virus } 1 \text { (HIV-1) }\end{array}$ & Retroviridae & + single strand ( 2 copies) & $\begin{array}{l}\text { Activation of ATR, replication stress, } \\
\text { activation of nucleases and formation } \\
\text { of DDR foci by Vpr }\end{array}$ & [92-95] \\
\hline $\begin{array}{l}\text { Human T-cell lymphotropic } \\
\text { virus } 1 \text { (HTLV-1) }\end{array}$ & Retroviridae & + single strand ( 2 copies) & $\begin{array}{l}\text { Genome instability and DNA } \\
\text { damage; attenuation of BER, NER, } \\
\text { MMR, HR, NHEJ pathways by Tax. } \\
\text { Generation of ROS }\end{array}$ & [96-98] \\
\hline Hepatitis $\mathrm{C}$ virus (HCV) & Flaviviridae & + single strand & $\begin{array}{l}\text { Generation of ROS and NO, reduced } \\
\text { expression of MMR, BER and NER } \\
\text { components, interaction of viral } \\
\text { proteins with ATM and modulation } \\
\text { of ATM pathway activity }\end{array}$ & [99-103] \\
\hline Infectious bronchitis virus (IBV) & Coronaviridae & + single strand & $\begin{array}{l}\text { Activation of ATR pathway and DNA } \\
\text { replication stress }\end{array}$ & {$[104]$} \\
\hline Influenza A virus & Orthomyxoviridae & - single strand & $\begin{array}{l}\text { Direct DNA damage (comet assay) } \\
\text { Induction of } \gamma \mathrm{H} 2 \mathrm{AX} \text { foci }\end{array}$ & {$[105,106]$} \\
\hline Chikungunya virus & Togaviridae & + single strand & Induction of GADD34 expression & [107] \\
\hline Sindbis virus & Togaviridae & + single strand & Activation of PARP-1 & [108] \\
\hline La Crosse virus & Bunyaviridae & - single strand & Increased phosphorylation of $\mathrm{H} 2 \mathrm{AX}$ & [109] \\
\hline Rift valley fever virus (RVFV) & Bunyaviridae & - single strand & $\begin{array}{l}\text { Activation of ATM signalling; } \\
\text { inhibition of ATR }\end{array}$ & [110] \\
\hline Avian Reovirus (ARV) & Reoviridae & double strand & $\begin{array}{l}\text { Genome instability and activation of } \\
\text { ATR signalling }\end{array}$ & [111] \\
\hline
\end{tabular}




\section{Retroviral Integration and the DDR}

Retroviruses are a unique class of intracellular parasites that include HIV-1 and HTLV-1. In order to replicate, retroviruses must reverse transcribe their RNA genome and integrate the subsequent DNA intermediate into the chromosomes of host cells (Figure 2). The viral integrase protein is essential in this process as it first catalyses the removal of two nucleotides from the 3'ends of the viral DNA and then participates in the joining of the exposed hydroxyl groups to staggered phosphates in the host chromatin [90]. Insertion of retroviral DNA results in the creation of DSBs and leaves single-strand gaps that flank the integration site and link viral and host DNA [90]. Efficient repair of these lesions is vital for host cell integrity and subsequent transcription of the viral genome. Since retroviral proteins with the ability to repair this damage have not been identified, it has long been speculated that host enzymes must fulfil the role [112].

Several studies examining the involvement of the host DDR in retroviral replication have identified the NHEJ pathway as central to post-integration DNA repair [113-118]. The infection of murine cells lacking DNA-PK, an essential enzyme in NHEJ, with three different retroviruses resulted in reduced viral DNA integration and high levels of apoptosis [113]. In addition, depletion of Ku80, another important NHEJ factor, has been shown to impede HIV-1 replication significantly [115,118]. The NHEJ pathway has also been implicated in the circularisation of unintegrated viral DNA that would otherwise be sensed as DNA damage by the cell and lead to apoptosis [114,115]. While there is significant evidence for the involvement of NHEJ in retroviral post-integration repair, efficient lentivirus transduction has been demonstrated in DNA-PK deficient cells suggesting that, at least in some circumstances, alternative repair pathways could be involved [119].
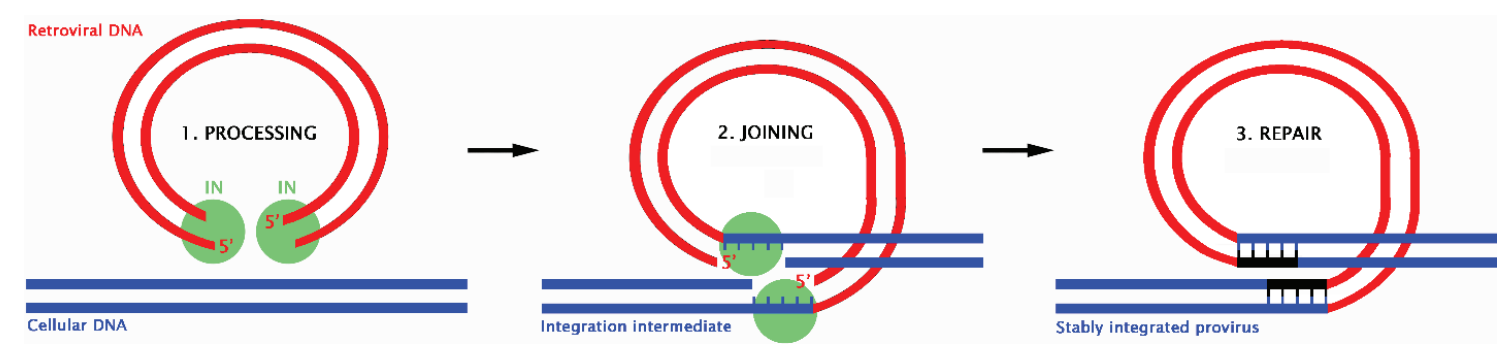

Figure 2. The basic steps in the retroviral integration process. 1. Viral integrase (IN) processes the viral DNA ends. 2. IN then catalyses the cleavage of host DNA and attachment of viral DNA forming an integration intermediate. 3. Finally, host factors repair the single strand gaps resulting in a stably integrated provirus. Image adapted from [120]. (2003) National Academy of Sciences, USA.

An examination of the role of the ATM and ATR kinases in retroviral integration has resulted in several conflicting reports. A reduction in retroviral transduction was observed in cells transfected with a dominant-negative form of the ATR gene but not in ATM-deficient cells, suggesting that the retroviral lifecycle relies on an ATR-dependent DDR [120,121]. In contrast, another study found that a small molecule inhibitor of ATM was able to suppress replication of both wild type and drug-resistant HIV-1, indicating a key role for this kinase in the viral lifecycle [122]. To add to the confusion, other researchers have questioned the importance of either kinase by showing that RNA interference of ATM and ATR as well as inhibition with caffeine (a general kinase inhibitor) had no effect on the efficiency of HIV-1 transduction or retroviral-induced apoptosis $[123,124]$. Subsequently, it was shown that the involvement of these DDR kinases in retroviral replication can vary between cell types which may partly explain the discrepancies observed in earlier studies [112].

PARP-1 has been implicated in SSB and DSB repair, DNA replication, genome stability, transcription and apoptosis [125]. As with ATM and ATR, there has been considerable disagreement over the role of PARP-1 in retroviral integration. Following experimental suppression of PARP-1 activity, several studies have claimed that this enzyme is essential for HIV integration [126-128] while 
others have stated that it is dispensable $[119,123,129]$. As well as the use of varying experimental conditions, the fact that PARP-1 is known to have overlapping roles with other members of the ARTD(PARP) family in mammalian cells may explain the lack of consensus in these reports [130,131]. More recently it has been shown that, rather than effecting viral DNA integration, PARP-1 promotes transcriptional repression of viral DNA post-integration via epigenetic mechanisms [132].

It is believed that minor SSBs can be repaired independently of ATM and ATR using the BER pathway [133]. A targeted siRNA screen against DNA repair genes revealed that inhibition of several factors involved in the short-patch BER pathway impeded HIV-1 replication [134]. Surprisingly, genes involved in NHEJ did not feature prominently in the screen [134]. A subsequent report indicated that the BER pathway is important for post-integration repair during lentiviral infection but less so for other retroviruses [135]. It was suggested that the sequence site preference for integration unique to each retrovirus may determine the choice of pathway for the subsequent repair process [135].

Questions remain over the importance of host DDR proteins in retroviral replication. The conflicting results from these studies may stem from the use of different cell types, many of which are not necessarily a representative model of in vivo retroviral replication, combined with the use of distinct vector-based transduction methods. In addition, many conclusions have been drawn from the use of non-specific inhibitors that are known to have off-target effects while negative RNA interference data may simply indicate that expression of only a small amount of a given protein is required during the replication process [112]. There is also evidence that the process of post-integration repair may be separate from classic DNA repair pathways which raises the possibility of inhibiting this process while leaving important cellular functions intact [136]. This could be particularly significant given that targeting of virally encoded proteins to treat HIV-1 infection has proved problematic due to the high mutation rate and short replication cycle of the virus [122].

\section{Human Immunodeficiency Virus 1 (HIV-1) Vpr Protein}

HIV-1 is a lentivirus that belongs to the Retroviridae family. Lentiviruses are characterised by an extended incubation period and are associated with chronic diseases that affect the immune and central nervous systems [137]. HIV-1 is well known as the causative agent of acquired immune deficiency syndrome (AIDS) which develops via the progressive depletion of CD4+ T cells. Along with structural and regulatory proteins, HIV-1 also encodes several accessory proteins which can contribute to HIV infectivity and pathogenesis [93]. The $14 \mathrm{kDa}$ viral protein $\mathrm{R}(\mathrm{Vpr})$ is one such accessory molecule that has been studied extensively in the context of its interaction with the host DDR. Vpr has multiple functions in the HIV-1 infection process including viral and host gene transcriptional co-activation, nuclear import of viral DNA, modulation of NF-kB activity as well as cell cycle and apoptotic regulation [138].

Vpr is able to modulate the host cell cycle and can arrest lymphocytes at G2/M by inhibiting activation of the cyclin B-Cdk1 complex [139-142]. Following cell cycle arrest, Vpr expression can promote apoptosis in infected cells [143-146] and this may contribute to the in vivo depletion of CD4+ T lymphocytes [138]. Regulation of the host cell cycle is believed to offer significant advantages to the virus during the early stages of infection [147]. There is also evidence that viral genome expression is optimal in G2 phase and that Vpr arrests cells at the point where the HIV-1 long terminal repeat (LTR) is most active in order to increase transcription of viral genes [148]. In addition, the presence of an internal ribosome entry site (IRES) in the HIV-1 genome could selectively enhance the translation of viral proteins during $\mathrm{G} 2$ arrest [149].

Expression of Vpr can cause DNA damage and activate DDR pathways and this has been proposed as the mechanism by which Vpr induces cell cycle arrest in G2. Using a pulsed-field gel electrophoresis (PFGE) assay, it was shown that Vpr can induce DSBs and that formation of these DNA lesions was dependent on the ability of Vpr to bind to chromatin [94]. The same group subsequently showed that Vpr expression activates the ATM-CHK2 pathway and upregulates HR repair which was demonstrated by an increase in formation of RAD51 and BRCA1 foci [150]. The authors suggest that DSB formation 
and ATM activation by Vpr may enhance HIV-1 integration efficiency as well as contributing to HIV-1 pathogenesis.

Several studies have shown that activation of the ATR-CHK1 pathways is specifically required for Vpr-mediated G2 arrest [93,151-153]. One study demonstrated that Vpr can bind directly to host DNA, potentially interfering with DNA replication and resulting in the accumulation of chromatin-associated RPA which then activates ATR [93]. The same study failed to detect DSB formation or ATM activation following Vpr expression suggesting that the ATM-CHK2 arm of the DDR may be dispensable for Vpr-induced cell cycle arrest. Additional studies have provided evidence that Vpr causes replication stress in CD4+ T cells that leads to formation of RPA foci and activation of ATR and several downstream substrates [95,153]. However, it has subsequently been argued that Vpr induces G2 arrest via a molecular mechanism that is distinct from that induced by DNA damage or replication stress [154,155]. It was shown that exposing cells to agents that typically induce ATR/CHK1 activation, such as UV and hydroxyurea, resulted in Cdc25A degradation and S-phase arrest. Although expression of Vpr also caused phosphorylation of CHK1 in S-phase, the Vpr-expressing cells were able to proceed to G2 with Cdc25A levels largely unaffected [155]. These finding are supported by an earlier study using inhibitors of DDR kinases which found that accumulation of cells in G2 is mediated by Vpr in a mechanism that is distinct from that induced by DNA damage [144].

Vpr-induced cell cycle arrest via ATR activation has also been linked to the manipulation of the ubiquitin proteasome system (UPS). Manipulation of the host UPS has been observed in several unrelated viruses including human papillomavirus (HPV) [156], hepatitis B virus (HBV) [157] and paramyxovirus (PMV) [158] and can induce the polyubiquitination and degradation of cellular factors that ultimately aid viral replication. Vpr binding of both Cul4A and DDB1, components of the DDB1-CUL4A-RBX1 E3 ligase complex, via interaction with VPRBP is believed to cause ATR activation and G2 arrest through the ubiquitination of an unknown target $[159,160]$. Inhibition of K48 polyubiquitination significantly reduces the formation of Vpr-induced $\gamma \mathrm{H} 2 \mathrm{AX}$ foci but not UV-induced $\gamma \mathrm{H} 2 \mathrm{AX}$ foci [161]. It has been postulated that Vpr may trigger degradation of DNA repair regulators and lead to recruitment of DNA repair proteins in the absence of replication stress [161]. More recently, Vpr was found to interact with SLX4, a nuclease scaffold protein involved in the Fanconi anemia repair pathway [92]. Recruitment of VPRBP and PLK1 following Vpr-SLX4 binding was shown to cause premature activation of SLX4-associated MUS81-EME1 endonucleases leading to replication stress through abnormal processing of stalled replication forks. The Vpr-SLX4 interaction led to an accumulation of FANCD2 foci, indicating DNA damage in S-phase, and was also required for Vpr-mediated G2/M arrest. The presence of Vpr and SLX4 also suppressed induction of type 1 interferon by HIV-1 and it was suggested that Vpr may induce SLX4 to process viral DNA that would otherwise accumulate and trigger an immune response.

The ability of Vpr to cause cell cycle arrest in G2 is a well-established phenomenon although the mechanism behind it is still under debate. Vpr expression can increase the occurrence of several markers of DNA damage and, in addition to the studies mentioned above, Vpr has also been linked to an increase in intracellular ROS levels which are known to cause DNA damage during infection by several RNA viruses $[162,163]$. Despite these observations, the requirement for DDR activation in cell cycle modulation by $\mathrm{Vpr}$ has been questioned by more than one study suggesting that downstream signalling may be modulated by HIV-1 [144,155]. The capacity of Vpr to induce cell cycle arrest and apoptosis in a p53-independent manner has led to the proposal that it could function as an anti-cancer agent if delivered via a genetically modified oncolytic virus [164]. However, as with other chemotherapeutic agents, its effectiveness may be limited by the potential of Vpr to induce significant genetic instability in otherwise healthy cells $[94,165]$.

\section{Human T-Cell Lymphotropic Virus Type 1 (HTLV-1) Tax Protein}

HTLV-1 is another member of the Retroviridae family and the etiological agent of the aggressive CD4+ T cell proliferative malignancy, adult T-cell leukemia (ATL), as well as a progressive neurological 
disease known as HTLV-1-Associated Myelopathy/Tropical Spastic Paraparesis (HAM/TSP). As well as the structural proteins common to all retroviruses, HTLV-1 also encodes a number of regulatory and accessory proteins that include a $40 \mathrm{kDa}$ viral transactivator known as Tax. Tax has been classified as a viral oncoprotein and is essential for cellular transformation following HTLV-1 infection [166]. As well as activating cellular pathways that promote cellular proliferation and interfering with tumour suppressor function, Tax can also disrupt cell cycle progression, introduce DNA damage and interfere with DNA repair [167].

Tax expression can increase intracellular ROS levels through an interaction with ubiquitin-specific protease 10 (USP10), which inhibits its antioxidant activity, as well as through activation of the transcription factors NF-KB and CREB [168,169]. ROS induced by Tax has been shown to cause DNA damage in T cells and fibroblasts and increase the expression of the senescence marker SEN1 [170]. The ability of Tax to activate the NF- $\mathrm{B}$ pathway has also been linked to the formation of DSBs due to stimulation of nitric oxide (NO) production [171]. As well as increasing ROS/NO-induced DNA damage, Tax expression also leads to down-regulation of DNA polymerase $\beta$, a key component of the BER pathway that is primarily responsible for correcting oxidative DNA lesions [172]. An additional study found BER repair was impaired in HTLV-1-infected cells and in those expressing Tax alone [96].

HTLV-1 is known to enhance proliferation of infected cells and multiple studies have implicated Tax in dysregulation of the cell cycle [89]. Tax can both impair the recruitment of MDC1 to repair foci and reduce phosphorylation of $\mathrm{H} 2 \mathrm{AX}$ and RPA by enhancing expression of the cellular phosphatase WIP1 [98,173]. Inference with activation and recruitment of key DDR proteins allows Tax-expressing cells to enter S-phase with unrepaired DNA damage. Tax expression can also accelerate S-phase progression through interaction with the MCM2-7 complex and replication origins [174]. The unlicensed firing of replication origins can result in replicative stress and genomic lesions. In line with these findings, a separate study showed that ectopic expression of Tax leads to DSB formation during DNA replication in S-phase [97]. In addition, the authors demonstrated that HR repair of these lesions was compromised in favour of the more error-prone NHEJ repair pathway. A subsequent study by the same group confirmed that Tax can interfere with host DNA replication leading to firing of backup replication origins and DNA damage [171]. Increased DNA damage following expression of Tax in cells already deficient in HR provides evidence that Tax can cause damage independently of its ability to depress HR function.

Tax can also interact with cell cycle checkpoint kinases and compromise the ability of the host cell to arrest and engage DNA repair pathways following DNA damage. Tax can bind to CHK1, inhibit its kinase activity and attenuate the G2 checkpoint following treatment with IR [175]. Tax can also interact with the kinase domain of CHK2 and impair its role in the DDR by inhibiting its dissociation from chromatin [176]. Tax and CHK2 co-localise in nuclear speckled structures that also contain other DDR factors such as 53BP1 and DNA-PKcs $[177,178]$. Tax can also abrogate the G1 checkpoint following UV-induced DNA damage in both p53+ and p53- cells [177].

HTLV-1 Tax causes DNA damage in host cells through elevated oxidative stress and stimulation of unregulated DNA replication while concurrently undermining cell cycle checkpoints and multiple DNA repair pathways. While there are many aspects to the oncogenic activities of the Tax protein, it is clear that its ability to introduce DNA lesions and modulate the ensuing cellular response will contribute significantly to the chromosomal instability that characterises HTLV-1-associated malignancies.

\section{Hepatitis C Virus (HCV)}

$\mathrm{HCV}$ is a small positive-sense single-stranded RNA virus with a genome of 9.6kb [179]. HCV is hepatotrophic and causes acute and chronic hepatitis, while persistent infection can lead to the development of liver cirrhosis and hepatocellular carcinoma (HCC) [180]. The HCV genome encodes a polyprotein precursor that is cleaved by host and viral proteases to produce at least 10 mature structural and non-structural (NS) proteins [179]. HCV infection can stimulate the production of 
NO via activation of inducible NO synthase (iNOS) as well as amplifying the release of ROS in host cells $[99,100]$. The accumulation of DSBs and genetic abnormalities in HCV-infected cells has been attributed to the elevated levels of NO and ROS which can overwhelm host repair mechanisms and potentially drive the progression of HCV-associated malignancies $[99,100]$.

As well as inducing DNA damage, $\mathrm{HCV}$ can inhibit host DNA repair pathways, often through the direct interaction of viral proteins with host DDR factors. Human liver hepatocellular carcinoma cells expressing the $\mathrm{HCV}$ core protein are less able to repair UV-induced DNA damage than those expressing an empty vector [181]. In addition, reduced expression of the MMR genes MSH2, MLH1, MSH6 and PMS2 has also been reported in multiple cases of HCV-associated hepatocellular carcinoma [182]. BER, and to a lesser extent NER, are responsible for the reversal of oxidative damage to DNA [183]. Reduced expression of the NEIL1 glycosylase, involved in cleaving damaged bases during the initial steps of BER, has been observed in HCV-infected cell cultures and in primary tissue samples from patients with advanced liver disease associated with HCV infection [184]. Furthermore, mice hepatocytes expressing the entire HCV open reading frame (ORF) exhibited defective cell cycle arrest and reduced NER through the down-regulation of Gadd $45 \beta$ [185].

$\mathrm{HCV}$ proteins have also been found to interfere with the ATM-CHK2 pathway that is typically activated in response to DSBs. The HCV protease NS3/4A can interact with ATM causing its cytoplasmic translocation and rendering cells more sensitive to DNA damage induced by IR [103]. Furthermore, HCV core protein can interact with NBS1 and inhibit ATM activation by interfering with the formation of the MRN complex at the sites of DSBs [101]. Expression of NS2 alone can lead to phosphorylation of the ATM substrate $\mathrm{CHK} 2$, although this viral protein has also been shown to inhibit downstream signalling by mislocalising p53 from the nucleus to the cytoplasm [186]. Despite the observation that HCV proteins can impair ATM signalling, it has also been demonstrated that inhibition of this DDR pathway suppresses replication of HCV. This suggests that HCV may hijack certain DDR factors associated with the ATM pathway in order to replicate its genome [102]. As has been suggested with HIV-1, the use of small molecule inhibitors against ATM could be used to impede viral replication and aid in the treatment of HCV-related diseases [102].

\section{Infectious Bronchitis Virus (IBV)}

IBV is a highly infectious avian gamma-coronavirus that primarily targets cells of the respiratory tract [187]. Coronaviruses comprise a diverse group of enveloped positive-strand RNA viruses that are responsible for several human diseases, most notably the severe acute respiratory syndrome (SARS) epidemic in 2003. Coronaviruses form replication complexes in association with intracellular membranes and the $27.6 \mathrm{~kb}$ genome encodes replicase proteins and four major structural proteins [188].

IBV infection can inhibit cell growth by inducing cell cycle arrest in G2 and S-phases in both wild type and p53-null cells $[189,190]$. Infection of cultured cells with IBV activates the ATR-CHK1 pathway underlined by phosphorylation of H2AX, RPA2 and CHK1 [104]. Furthermore, inhibition of ATR by RNA interference and small molecule inhibitors reduces coronavirus replication while inhibition of DNA-PK and ATM has no effect [104]. DNA replication stress may be induced by IBV via an interaction between the coronavirus non-structural protein nsp13 and DNA polymerase $\delta$ which can then lead to ATR activation and S-phase arrest [104]. This ATR-induced cell cycle arrest appears to promote conditions that are favourable to both viral RNA and cellular DNA replication [104,189,190]. Although DNA duplication occurs in the nucleus while coronaviruses replicate exclusively in the cytoplasm, it has been suggested that S-phase extension benefits both processes because IBV can mediate the translocation of abundant host factors between the nucleus and sites of viral replication $[104,191]$.

\section{Influenza A Virus}

Influenza $\mathrm{A}$ is an enveloped virus that is part of the Orthomyxoviridae family that also contains type $B$ and $C$ influenza viruses. Influenza A has a negative-sense single-stranded RNA genome consisting of eight ribonucleoprotein complexes that encode 11 viral genes [192]. Following cell entry, 
the negative-sense viral RNA is transported to the nucleus where it provides a template for production of positive-sense mRNA molecules which are then exported to the cytoplasm for translation of viral proteins [192]. Influenza viruses target cells in the upper respiratory tract and are a significant source of human morbidity and mortality through the development and spread of flu. Several subtypes of influenza A have been identified based on variations in viral envelope surface proteins, haemagglutinin (HA) and neuraminidase (NA) [193].

Comet assays have revealed that the influenza A subtype H3N2 can cause DNA damage in leukocytes as early as $2 \mathrm{~h}$ post infection [106]. DNA damage was maximal after $24 \mathrm{~h}$ although significant cell death was not observed until after $96 \mathrm{~h}$ suggesting that infected cells may continue to proliferate in the presence of deleterious mutations. A subsequent study found that infection with the same influenza subtype causes extensive chromatin condensation and fragmentation of DNA into oligonucleosomes consistent with apoptotic cell death [194]. Another major influenza A subtype, H1N1, was shown to induce DNA strand breaks, measured by appearance of $\gamma \mathrm{H} 2 \mathrm{AX}$ foci, in both epithelial cells and immune cells [105]. DNA damage persisted after viral clearance and correlated with elevated oxidative stress associated with viral infection. The host inflammatory response appears to be at least partially responsible for DNA damage caused by influenza A infection which subsequently plays a role in localised tissue damage that characterises viral disease. It has yet to be determined which specific influenza A proteins are responsible for DNA damage induction and whether particular repair pathways are compromised by the virus.

\section{Conclusions}

Viruses with RNA genomes are responsible for the emergence of numerous high-profile infectious diseases that include AIDS and SARS, as well as being the causative agents of several aggressive malignancies. Substantial genetic diversity and high mutation rates in these cases have often confounded therapeutic intervention strategies and intensified the need for greater understanding of RNA virus lifecycles. In this regard, there is considerable interest in how the interaction between these pathogens and essential cellular processes, such as the DDR, contribute to viral propagation and pathogenesis.

While all the viruses mentioned above have the potential to introduce genetic instability during the course of infection, the exact mechanism by which DNA lesions are inflicted is often difficult to establish. Viruses typically modulate cell cycle progression and apoptotic pathways in order to ensure efficient and complete replication of their genetic material. Changes that lead to enhanced cellular proliferation and weakening of cell cycle checkpoints can result in replication-induced DNA damage that fails to trigger cell cycle arrest or activation of DNA repair pathways. Furthermore, increased generation of ROS is a common feature of RNA virus infection and is a well-characterised source of endogenous DNA damage $[183,195]$. The SSBs and base damage typically inflicted by ROS can frequently lead to more deleterious DSBs by impeding DNA replication machinery resulting in fork stalling and collapse [196]. While the process of retroviral integration triggers upregulation of DNA repair pathways, several retroviral proteins are known to cause DNA damage and suppress DNA repair. As such, RNA viruses may have conflicting interactions with the DDR at several stages during their replicative cycles and can potentially inflict DNA damage through both direct and indirect mechanisms.

While DDR activation following viral entry into the cell can represent an antiviral response that leads to apoptosis of the infected cell, RNA viruses can also selectively trigger DDR signalling to promote cellular conditions that are favourable for viral replication, as is the case with many DNA viruses. The Rift Valley fever virus (RVFV), a negative-strand RNA virus of the Bunyaviridae family, encodes a non-structural (NSs) protein that causes S-phase arrest by activating the ATM-CHK2 pathway [110]. Chemical inhibition of ATM signalling during RVFV infection both rescues cells from S-phase stasis and significantly reduces levels of viral replication. In this case, it appears that the link between DDR activation and cell cycle regulation is exploited to ensure maximal production of 
progeny virus. The NSs protein of another member of the Bunyaviridae family, the La Crosse virus (LACV), inhibits the type 1 interferon response through degradation of the RNA polymerase II subunit RPB1 [109]. There is evidence that selective activation of DDR components by NSs could be crucial to promoting RPB1 proteasomal degradation. In the case of LACV, limited stimulation of DDR pathways may be part of a strategy to moderate the innate immune response while detrimental effects of wider DDR activation are circumvented. RNA viruses can also acquire a survival advantage by targeting specific DDR proteins. The HIV-1 Tat protein, for example, can suppress the activity of Tip60, a histone acetyltransferase involved in ATM activation. This interaction leads to the suppression of the apoptotic response following DNA damage and could therefore promote viral replication through prolonged survival of the host cell [197]. HIV-1 Tat also downregulates expression of DNA-PKcs, a core factor in NHEJ repair, which sensitises Tat-expressing cells to the effects of IR [198]. More recently this interaction has been shown to impair the role of DNA-PKcs in B-cell antibody class switch recombination, providing a possible mechanism in which HIV-1 could regulate humoral immunity [199].

Regardless of the exact source of DNA damage or consequence of DDR activation during RNA virus lifecycles, increased genetic instability plays a considerable role in the pathogeneses of the viruses discussed here and is likely to be a key factor driving cellular transformation by those species associated with tumour development. Currently, specific cases regarding interactions between RNA viruses and the DDR are less numerous than in DNA viruses and understandably research has focused on those species that are important human health concerns. However, there is no doubt that more examples and increasing layers of complexity will emerge as the field develops.

Acknowledgments: We are most grateful to MRC and the University of Birmingham and Cancer Research UK for financial support in the form of studentships to E.R. and R.H. We are also grateful to John Reynolds, Grant Stewart and Martin Higgs for helpful discussion.

Author Contributions: All authors contributed equally to writing the manuscript.

Conflicts of Interest: The authors have no conflicting interests.

\section{References}

1. Tao, Y.J.; Ye, Q. RNA virus replication complexes. PLoS Pathog. 2010, 6, e1000943. [CrossRef] [PubMed]

2. Drake, J.W. Rates of spontaneous mutation among RNA viruses. Proc. Natl. Acad. Sci. USA 1993, 90, 4171-4175. [CrossRef] [PubMed]

3. Steinhauer, D.A.; Domingo, E.; Holland, J.J. Lack of evidence for proofreading mechanisms associated with an RNA virus polymerase. Gene 1992, 122, 281-288. [CrossRef]

4. Belshaw, R.; Pybus, O.G.; Rambaut, A. The evolution of genome compression and genomic novelty in RNA viruses. Genome Res. 2007, 17, 1496-1504. [CrossRef] [PubMed]

5. Denison, M.R. Seeking membranes: Positive-strand RNA virus replication complexes. PLoS Biol. 2008, 6, e270. [CrossRef] [PubMed]

6. Zhou, H.; Sun, Y.; Guo, Y.; Lou, Z. Structural perspective on the formation of ribonucleoprotein complex in negative-sense single-stranded RNA viruses. Trends Microbiol. 2013, 21, 475-484. [CrossRef] [PubMed]

7. D'Souza, V.; Summers, M.F. How retroviruses select their genomes. Nat. Rev. Microbiol. 2005, 3, $643-655$. [CrossRef] [PubMed]

8. Quinn, T.P.; Grandgenett, D.P. Genetic evidence that the avian retrovirus DNA endonuclease domain of pol is necessary for viral integration. J. Virol. 1988, 62, 2307-2312. [PubMed]

9. Caly, L.; Wagstaff, K.M.; Jans, D.A. Nuclear trafficking of proteins from RNA viruses: Potential target for antivirals? Antiviral.Res. 2012, 95, 202-206. [CrossRef] [PubMed]

10. Jackson, S.P.; Bartek, J. The DNA-damage response in human biology and disease. Nature 2009, 461, 1071-1078. [CrossRef] [PubMed]

11. Caldecott, K.W. Mammalian single-strand break repair: Mechanisms and links with chromatin. DNA Repair 2007, 6, 443-453. [CrossRef] [PubMed] 
12. Ghosal, G.; Chen, J. DNA damage tolerance: A double-edged sword guarding the genome. Transl. Cancer Res. 2013, 2, 107-129. [PubMed]

13. Yang, J.; Yu, Y.; Hamrick, H.E.; Duerksen-Hughes, P.J. ATM, ATR and DNA-PK: Initiators of the cellular genotoxic stress responses. Carcinogenesis 2003, 24, 1571-1580. [CrossRef] [PubMed]

14. Ciccia, A.; Elledge, S.J. The DNA damage response: Making it safe to play with knives. Mol. Cell 2010, 40, 179-204. [CrossRef] [PubMed]

15. Turnell, A.S.; Grand, R.J. DNA viruses and the cellular DNA-damage response. J. Gen. Virol. 2012, 93, 2076-2097. [CrossRef] [PubMed]

16. Lieber, M.R. The mechanism of double-strand DNA break repair by the nonhomologous DNA end-joining pathway. Annu. Rev. Biochem. 2010, 79, 181-211. [CrossRef] [PubMed]

17. Lee, J.H.; Paull, T.T. ATM activation by DNA double-strand breaks through the Mre11-Rad50-Nbs1 complex. Science 2005, 308, 551-554. [CrossRef] [PubMed]

18. Falck, J.; Coates, J.; Jackson, S.P. Conserved modes of recruitment of ATM, ATR and DNA-PKcs to sites of DNA damage. Nature 2005, 434, 605-611. [CrossRef] [PubMed]

19. Cimprich, K.A.; Cortez, D. ATR: An essential regulator of genome integrity. Nat. Rev. Mol. Cell Biol. 2008, 9, 616-627. [CrossRef] [PubMed]

20. Stewart, G.S.; Wang, B.; Bignell, C.R.; Taylor, A.M.; Elledge, S.J. MDC1 is a mediator of the mammalian DNA damage checkpoint. Nature 2003, 421, 961-966. [CrossRef] [PubMed]

21. Stewart, G.S.; Panier, S.; Townsend, K.; Al-Hakim, A.K.; Kolas, N.K.; Miller, E.S.; Nakada, S.; Ylanko, J.; Olivarius, S.; Mendez, M.; et al. The RIDDLE syndrome protein mediates a ubiquitin-dependent signaling cascade at sites of DNA damage. Cell 2009, 136, 420-434. [CrossRef] [PubMed]

22. Huyen, Y.; Zgheib, O.; Ditullio, R.A., Jr.; Gorgoulis, V.G.; Zacharatos, P.; Petty, T.J.; Sheston, E.A.; Mellert, H.S.; Stavridi, E.S.; Halazonetis, T.D. Methylated lysine 79 of histone H3 targets 53BP1 to DNA double-strand breaks. Nature 2004, 432, 406-411. [CrossRef] [PubMed]

23. Zou, L.; Elledge, S.J. Sensing DNA damage through ATRIP recognition of RPA-ssDNA complexes. Science 2003, 300, 1542-1548. [CrossRef] [PubMed]

24. Kumagai, A.; Lee, J.; Yoo, H.Y.; Dunphy, W.G. TopBP1 activates the ATR-ATRIP complex. Cell 2006, 124, 943-955. [CrossRef] [PubMed]

25. Bartek, J.; Lukas, J. Mammalian G1- and S-phase checkpoints in response to DNA damage. Curr. Opin. Cell Biol. 2001, 13, 738-747. [CrossRef]

26. Costanzo, V.; Robertson, K.; Ying, C.Y.; Kim, E.; Avvedimento, E.; Gottesman, M.; Grieco, D.; Gautier, J. Reconstitution of an ATM-dependent checkpoint that inhibits chromosomal DNA replication following DNA damage. Mol. Cell 2000, 6, 649-659. [CrossRef]

27. Harper, J.W.; Elledge, S.J.; Keyomarsi, K.; Dynlacht, B.; Tsai, L.H.; Zhang, P.; Dobrowolski, S.; Bai, C.; Connell-Crowley, L.; Swindell, E.; et al. Inhibition of cyclin-dependent kinases by p21. Mol. Biol. Cell 1995, 6, 387-400. [CrossRef] [PubMed]

28. Falck, J.; Petrini, J.H.; Williams, B.R.; Lukas, J.; Bartek, J. The DNA damage-dependent intra-S phase checkpoint is regulated by parallel pathways. Nat. Genet. 2002, 30, 290-294. [CrossRef] [PubMed]

29. Yazdi, P.T.; Wang, Y.; Zhao, S.; Patel, N.; Lee, E.Y.; Qin, J. SMC1 is a downstream effector in the ATM/NBS1 branch of the human S-phase checkpoint. Genes Dev. 2002, 16, 571-582. [CrossRef] [PubMed]

30. O'Connor, P.M.; Ferris, D.K.; Hoffmann, I.; Jackman, J.; Draetta, G.; Kohn, K.W. Role of the cdc25C phosphatase in G2 arrest induced by nitrogen mustard. Proc. Natl. Acad. Sci. USA 1994, 91, 9480-9484. [CrossRef] [PubMed]

31. Perry, J.A.; Kornbluth, S. Cdc25 and Wee1: Analogous opposites? Cell Div. 2007. [CrossRef] [PubMed]

32. Suwa, A.; Hirakata, M.; Takeda, Y.; Jesch, S.A.; Mimori, T.; Hardin, J.A. DNA-dependent protein-kinase (Ku Protein-P350 Complex) assembles on double-stranded DNA. Proc. Natl. Acad. Sci. USA 1994, 91, 6904-6908. [CrossRef] [PubMed]

33. Leber, R.; Wise, T.W.; Mizuta, R.; Meek, K. The XRCC4 gene product is a target for and interacts with the DNA-dependent protein kinase. J. Biol. Chem. 1998, 273, 1794-1801. [CrossRef] [PubMed]

34. Matsumoto, Y.; Suzuki, N.; Namba, N.; Umeda, N.; Ma, X.J.; Morita, A.; Tomita, M.; Enomoto, A.; Serizawa, S.; Hirano, K.; et al. Cleavage and phosphorylation of XRCC4 protein induced by X-irradiation. FEBS Lett. 2000, 478, 67-71. [CrossRef] 
35. Calsou, P.; Delteil, C.; Frit, P.; Droulet, J.; Salles, B. Coordinated assembly of Ku and p460 subunits of the DNA-dependent protein kinase on DNA ends is necessary for XRCC4-ligase IV recruitment. J. Mol. Biol. 2003, 326, 93-103. [CrossRef]

36. Lieber, M.R.; Gu, J.; Lu, H.; Shimazaki, N.; Tsai, A.G. Nonhomologous DNA end joining (NHEJ) and chromosomal translocations in humans. Subcell. Biochem. 2010, 50, 279-296. [PubMed]

37. Baumann, P.; West, S.C. Role of the human RAD51 protein in homologous recombination and double-stranded-break repair. Trends Biochem. Sci. 1998, 23, 247-251. [CrossRef]

38. Shinagawa, H.; Iwasaki, H. Processing the holliday junction in homologous recombination. Trends Biochem. Sci. 1996, 21, 107-111. [CrossRef]

39. Caldecott, K.W. Single-strand break repair and genetic disease. Nat. Rev. Genet. 2008, 9, 619-631. [PubMed]

40. David, S.S.; O'Shea, V.L.; Kundu, S. Base-excision repair of oxidative DNA damage. Nature 2007, 447, 941-950. [CrossRef] [PubMed]

41. David, S.S.; Williams, S.D. Chemistry of glycosylases and endonucleases involved in base-excision repair. Chem. Rev. 1998, 98, 1221-1262. [CrossRef] [PubMed]

42. Demple, B.; Sung, J.S. Molecular and biological roles of Ape1 protein in mammalian base excision repair. DNA Repair 2005, 4, 1442-1449. [CrossRef] [PubMed]

43. Tomkinson, A.E.; Chen, L.; Dong, Z.; Leppard, J.B.; Levin, D.S.; Mackey, Z.B.; Motycka, T.A. Completion of base excision repair by mammalian DNA ligases. Prog. Nucleic Acid Res. Mol. Biol. 2001, 68, 151-164. [PubMed]

44. Wood, R.D. DNA damage recognition during nucleotide excision repair in mammalian cells. Biochimie 1999, 81, 39-44. [CrossRef]

45. Graf, N.; Ang, W.H.; Zhu, G.; Myint, M.; Lippard, S.J. Role of endonucleases XPF and XPG in nucleotide excision repair of platinated DNA and cisplatin/oxaliplatin cytotoxicity. Chembiochem 2011, 12, 1115-1123. [CrossRef] [PubMed]

46. Moser, J.; Kool, H.; Giakzidis, I.; Caldecott, K.; Mullenders, L.H.F.; Fousteri, M.I. Sealing of chromosomal DNA nicks during nucleotide excision repair requires XRCC1 and DNA ligase III alpha in a cell-cycle-specific manner. Mol. Cell 2007, 27, 311-323. [CrossRef] [PubMed]

47. Shivji, M.K.K.; Kenny, M.K.; Wood, R.D. Proliferating cell nuclear antigen is required for DNA excision repair. Cell 1992, 69, 367-374. [CrossRef]

48. Drummond, J.T.; Li, G.M.; Longley, M.J.; Modrich, P. Isolation of an hMSH2-p160 heterodimer that restores DNA mismatch repair to tumor-cells. Science 1995, 268, 1909-1912. [CrossRef] [PubMed]

49. Palombo, F.; Iaccarino, I.; Nakajima, E.; Ikejima, M.; Shimada, T.; Jiricny, J. hMutS $\beta$, a heterodimer of hMSH2 and hMSH3, binds to insertion/deletion leaps in DNA. Curr. Biol. 1996, 6, 1181-1184. [CrossRef]

50. McCulloch, S.D.; Gu, L.Y.; Li, G.M. Bi-directional processing of DNA loops by mismatch repair-dependent and -independent pathways in human cells. J. Biol. Chem. 2003, 278, 3891-3896. [CrossRef] [PubMed]

51. Acharya, S.; Wilson, T.; Gradia, S.; Kane, M.F.; Guerrette, S.; Marsischky, G.T.; Kolodner, R.; Fishel, R. hMSH2 forms specific mispair-binding complexes with hMSH3 and hMSH6. Proc. Natl. Acad. Sci. USA 1996, 93, 13629-13634. [CrossRef] [PubMed]

52. Gu, L.Y.; Hong, Y.; McCulloch, S.; Watanabe, H.; Li, G.M. ATP-dependent interaction of human mismatch repair proteins and dual role of PCNA in mismatch repair. Nucleic Acids Res. 1998, 26, 1173-1178. [CrossRef] [PubMed]

53. Longley, M.J.; Pierce, A.J.; Modrich, P. DNA polymerase delta is required for human mismatch repair in vitro. J. Biol. Chem. 1997, 272, 10917-10921. [PubMed]

54. Roos, W.P.; Kaina, B. DNA damage-induced cell death by apoptosis. Trends Mol. Med. 2006, 12, 440-450. [CrossRef] [PubMed]

55. Shibue, T.; Suzuki, S.; Okamoto, H.; Yoshida, H.; Ohba, Y.; Takaoka, A.; Taniguchi, T. Differential contribution of Puma and Noxa in dual regulation of p53-mediated apoptotic pathways. EMBO J. 2006, 25, 4952-4962. [CrossRef] [PubMed]

56. Jacotot, E.; Ravagnan, L.; Loeffler, M.; Ferri, K.F.; Vieira, H.L.; Zamzami, N.; Costantini, P.; Druillennec, S.; Hoebeke, J.; Briand, J.P.; et al. The HIV-1 viral protein R induces apoptosis via a direct effect on the mitochondrial permeability transition pore. J. Exp. Med. 2000, 191, 33-46. [CrossRef] [PubMed]

57. Schultz-Cherry, S.; Dybdahl-Sissoko, N.; Neumann, G.; Kawaoka, Y.; Hinshaw, V.S. Influenza virus NS1 protein induces apoptosis in cultured cells. J. Virol. 2001, 75, 7875-7881. [CrossRef] [PubMed] 
58. Li, K.; Foy, E.; Ferreon, J.C.; Nakamura, M.; Ferreon, A.C.; Ikeda, M.; Ray, S.C.; Gale, M., Jr.; Lemon, S.M. Immune evasion by hepatitis $C$ virus NS3/4A protease-mediated cleavage of the Toll-like receptor 3 adaptor protein TRIF. Proc. Natl. Acad. Sci. USA 2005, 102, 2992-2997. [CrossRef] [PubMed]

59. You, L.R.; Chen, C.M.; Lee, Y.H. Hepatitis $C$ virus core protein enhances NF- $\mathrm{kB}$ signal pathway triggering by lymphotoxin- $\beta$ receptor ligand and tumor necrosis factor alpha. J. Virol. 1999, 73, 1672-1681. [PubMed]

60. Okada, N.; Lin, C.P.; Ribeiro, M.C.; Biton, A.; Lai, G.; He, X.; Bu, P.; Vogel, H.; Jablons, D.M.; Keller, A.C.; et al. A positive feedback between p53 and miR-34 miRNAs mediates tumor suppression. Genes Dev. 2014, 28, 438-450. [CrossRef] [PubMed]

61. Wei, W.; Ba, Z.; Gao, M.; Wu, Y.; Ma, Y.; Amiard, S.; White, C.I.; Rendtlew Danielsen, J.M.; Yang, Y.G.; Qi, Y. A role for small RNAs in DNA double-strand break repair. Cell 2012, 149, 101-112. [CrossRef] [PubMed]

62. Francia, S.; Michelini, F.; Saxena, A.; Tang, D.; de Hoon, M.; Anelli, V.; Mione, M.; Carninci, P.; d'Adda di Fagagna, F. Site-specific DICER and DROSHA RNA products control the DNA-damage response. Nature 2012, 488, 231-235. [CrossRef] [PubMed]

63. Sharma, V.; Misteli, T. Non-coding RNAs in DNA damage and repair. FEBS Lett. 2013, 587, $1832-1839$. [CrossRef] [PubMed]

64. Chowdhury, D.; Choi, Y.E.; Brault, M.E. Charity begins at home: Non-coding RNA functions in DNA repair. Nat Rev Mol Cell Biol 2013, 14, 181-189. [CrossRef] [PubMed]

65. Sharma, V.; Khurana, S.; Kubben, N.; Abdelmohsen, K.; Oberdoerffer, P.; Gorospe, M.; Misteli, T. A BRCA1-interacting lncRNA regulates homologous recombination. EMBO Rep. 2015, 16, 1520-1534. [CrossRef] [PubMed]

66. Weiden, M.D.; Ginsberg, H.S. Deletion of the E4 region of the genome produces adenovirus DNA concatemers. Proc. Natl. Acad. Sci. USA 1994, 91, 153-157. [CrossRef] [PubMed]

67. Querido, E.; Blanchette, P.; Yan, Q.; Kamura, T.; Morrison, M.; Boivin, D.; Kaelin, W.G.; Conaway, R.C.; Conaway, J.W.; Branton, P.E. Degradation of p53 by adenovirus E4orf6 and E1B55K proteins occurs via a novel mechanism involving a Cullin-containing complex. Genes Dev. 2001, 15, 3104-3117. [CrossRef] [PubMed]

68. Carson, C.T.; Schwartz, R.A.; Stracker, T.H.; Lilley, C.E.; Lee, D.V.; Weitzman, M.D. The Mre11 complex is required for ATM activation and the G2/M checkpoint. EMBO J. 2003, 22, 6610-6620. [CrossRef] [PubMed]

69. Stracker, T.H.; Lee, D.V.; Carson, C.T.; Araujo, F.D.; Ornelles, D.A.; Weitzman, M.D. Serotype-specific reorganization of the Mre11 complex by adenoviral E4orf3 proteins. J. Virol. 2005, 79, 6664-6673. [CrossRef] [PubMed]

70. Blackford, A.N.; Bruton, R.K.; Dirlik, O.; Stewart, G.S.; Taylor, A.M.; Dobner, T.; Grand, R.J.; Turnell, A.S. A role for E1B-AP5 in ATR signaling pathways during adenovirus infection. J. Virol. 2008, 82, 7640-7652. [CrossRef] [PubMed]

71. Shi, Y.; Dodson, G.E.; Shaikh, S.; Rundell, K.; Tibbetts, R.S. Ataxia-telangiectasia-mutated (ATM) is a T-antigen kinase that controls SV40 viral replication in vivo. J. Biol. Chem. 2005, 280, 40195-40200. [CrossRef] [PubMed]

72. Dahl, J.; You, J.; Benjamin, T.L. Induction and utilization of an ATM signaling pathway by polyomavirus. J. Virol. 2005, 79, 13007-13017. [CrossRef] [PubMed]

73. Zhao, X.; Madden-Fuentes, R.J.; Lou, B.X.; Pipas, J.M.; Gerhardt, J.; Rigell, C.J.; Fanning, E. Ataxia telangiectasia-mutated damage-signaling kinase- and proteasome-dependent destruction of Mre11-Rad50-Nbs1 subunits in Simian virus 40-infected primate cells. J. Virol. 2008, 82, 5316-5328. [CrossRef] [PubMed]

74. Ali, S.H.; Kasper, J.S.; Arai, T.; DeCaprio, J.A. Cul7/p185/p193 binding to simian virus 40 large T antigen has a role in cellular transformation. J. Virol. 2004, 78, 2749-2757. [CrossRef] [PubMed]

75. Kamranvar, S.A.; Masucci, M.G. The Epstein-Barr virus nuclear antigen-1 promotes telomere dysfunction via induction of oxidative stress. Leukemia 2011, 25, 1017-1025. [CrossRef] [PubMed]

76. Chen, Y.R.; Liu, M.T.; Chang, Y.T.; Wu, C.C.; Hu, C.Y.; Chen, J.Y. Epstein-Barr virus latent membrane protein 1 represses DNA repair through the PI3K/Akt/FOXO3a pathway in human epithelial cells. J. Virol. 2008, 82, 8124-8137. [CrossRef] [PubMed]

77. Liu, M.T.; Chen, Y.R.; Chen, S.C.; Hu, C.Y.; Lin, C.S.; Chang, Y.T.; Wang, W.B.; Chen, J.Y. Epstein-Barr virus latent membrane protein 1 induces micronucleus formation, represses DNA repair and enhances sensitivity to DNA-damaging agents in human epithelial cells. Oncogene 2004, 23, 2531-2539. [PubMed] 
78. Gruhne, B.; Sompallae, R.; Masucci, M.G. Three Epstein-Barr virus latency proteins independently promote genomic instability by inducing DNA damage, inhibiting DNA repair and inactivating cell cycle checkpoints. Oncogene 2009, 28, 3997-4008. [CrossRef] [PubMed]

79. Nikitin, P.A.; Yan, C.M.; Forte, E.; Bocedi, A.; Tourigny, J.P.; White, R.E.; Allday, M.J.; Patel, A.; Dave, S.S.; Kim, W.; et al. An ATM/Chk2-mediated DNA damage-responsive signaling pathway suppresses Epstein-Barr virus transformation of primary human B cells. Cell Host Microbe 2010, 8, 510-522. [CrossRef] [PubMed]

80. Choudhuri, T.; Verma, S.C.; Lan, K.; Murakami, M.; Robertson, E.S. The ATM/ATR signaling effector Chk2 is targeted by Epstein-Barr virus nuclear antigen 3C to release the G2/M cell cycle block. J. Virol. 2007, 81, 6718-6730. [CrossRef] [PubMed]

81. Weitzman, M.D.; Lilley, C.E.; Chaurushiya, M.S. Genomes in conflict: maintaining genome integrity during virus infection. Annu. Rev. Microbiol. 2010, 64, 61-81. [CrossRef] [PubMed]

82. McFadden, K.; Luftig, M.A. Interplay between DNA tumor viruses and the host DNA damage response. Curr. Top. Microbiol. Immunol. 2013, 371, 229-257. [PubMed]

83. Chaurushiya, M.S.; Weitzman, M.D. Viral manipulation of DNA repair and cell cycle checkpoints. DNA Repair 2009, 8, 1166-1176. [CrossRef] [PubMed]

84. Weitzman, M.D.; Lilley, C.E.; Chaurushiya, M.S. Changing the ubiquitin landscape during viral manipulation of the DNA damage response. FEBS Lett. 2011, 585, 2897-2906. [CrossRef] [PubMed]

85. Wallace, N.A.; Galloway, D.A. Manipulation of cellular DNA damage repair machinery facilitates propagation of human papillomaviruses. Semin. Cancer Biol. 2014, 26, 30-42. [CrossRef] [PubMed]

86. Xiaofei, E.; Kowalik, T.F. The DNA damage response induced by infection with human cytomegalovirus and other viruses. Viruses 2014, 6, 2155-2185. [PubMed]

87. Luo, Y.; Qiu, J. Parvovirus infection-induced DNA damage response. Future Virol. 2013, 8, 245-257. [CrossRef] [PubMed]

88. Higgs, M.R.; Chouteau, P.; Lerat, H. "Liver let die": Oxidative DNA damage and hepatotropic viruses. J. Gen. Virol. 2014, 95, 991-1004. [CrossRef] [PubMed]

89. Marriott, S.J.; Semmes, O.J. Impact of HTLV-I Tax on cell cycle progression and the cellular DNA damage repair response. Oncogene 2005, 24, 5986-5995. [CrossRef] [PubMed]

90. Skalka, A.M.; Katz, R.A. Retroviral DNA integration and the DNA damage response. Cell Death Differ. 2005, 12, 971-978. [CrossRef] [PubMed]

91. Paracha, U.Z.; Fatima, K.; Alqahtani, M.; Chaudhary, A.; Abuzenadah, A.; Damanhouri, G.; Qadri, I. Oxidative stress and hepatitis $C$ virus. Virol. J. 2013. [CrossRef] [PubMed]

92. Laguette, N.; Bregnard, C.; Hue, P.; Basbous, J.; Yatim, A.; Larroque, M.; Kirchhoff, F.; Constantinou, A.; Sobhian, B.; Benkirane, M. Premature activation of the SLX4 complex by Vpr promotes G2/M arrest and escape from innate immune sensing. Cell 2014, 156, 134-145. [CrossRef] [PubMed]

93. Lai, M.; Zimmerman, E.S.; Planelles, V.; Chen, J. Activation of the ATR pathway by human immunodeficiency virus type 1 Vpr involves its direct binding to chromatin in vivo. J. Virol. 2005, 79, 15443-15451. [CrossRef] [PubMed]

94. Tachiwana, H.; Shimura, M.; Nakai-Murakami, C.; Tokunaga, K.; Takizawa, Y.; Sata, T.; Kurumizaka, H.; Ishizaka, Y. HIV-1 Vpr induces DNA double-strand breaks. Cancer Res. 2006, 66, 627-631. [CrossRef] [PubMed]

95. Zimmerman, E.S.; Sherman, M.P.; Blackett, J.L.; Neidleman, J.A.; Kreis, C.; Mundt, P.; Williams, S.A.; Warmerdam, M.; Kahn, J.; Hecht, F.M.; et al. Human immunodeficiency virus type 1 Vpr induces DNA replication stress in vitro and in vivo. J. Virol. 2006, 80, 10407-10418. [CrossRef] [PubMed]

96. Philpott, S.M.; Buehring, G.C. Defective DNA repair in cells with human T-cell leukemia/bovine leukemia viruses: Role of tax gene. J. Natl. Cancer Inst. 1999, 91, 933-942. [CrossRef] [PubMed]

97. Baydoun, H.H.; Bai, X.T.; Shelton, S.; Nicot, C. HTLV-I tax increases genetic instability by inducing DNA double strand breaks during DNA replication and switching repair to NHEJ. PLoS ONE 2012, 7, e42226. [CrossRef] [PubMed]

98. Chandhasin, C.; Ducu, R.I.; Berkovich, E.; Kastan, M.B.; Marriott, S.J. Human T-cell leukemia virus type 1 tax attenuates the ATM-mediated cellular DNA damage response. J. Virol. 2008, 82, 6952-6961. [CrossRef] [PubMed] 
99. Machida, K.; Cheng, K.T.; Sung, V.M.; Lee, K.J.; Levine, A.M.; Lai, M.M. Hepatitis C virus infection activates the immunologic (type II) isoform of nitric oxide synthase and thereby enhances DNA damage and mutations of cellular genes. J. Virol. 2004, 78, 8835-8843. [CrossRef] [PubMed]

100. Machida, K.; Cheng, K.T.; Lai, C.K.; Jeng, K.S.; Sung, V.M.; Lai, M.M. Hepatitis C virus triggers mitochondrial permeability transition with production of reactive oxygen species, leading to DNA damage and STAT3 activation. J. Virol. 2006, 80, 7199-7207. [CrossRef] [PubMed]

101. Machida, K.; McNamara, G.; Cheng, K.T.; Huang, J.; Wang, C.H.; Comai, L.; Ou, J.H.; Lai, M.M. Hepatitis C virus inhibits DNA damage repair through reactive oxygen and nitrogen species and by interfering with the ATM-NBS1/Mre11/Rad50 DNA repair pathway in monocytes and hepatocytes. J. Immunol. 2010, 185, 6985-6998. [CrossRef] [PubMed]

102. Ariumi, Y.; Kuroki, M.; Dansako, H.; Abe, K.; Ikeda, M.; Wakita, T.; Kato, N. The DNA damage sensors ataxia-telangiectasia mutated kinase and checkpoint kinase 2 are required for hepatitis $C$ virus RNA replication. J. Virol. 2008, 82, 9639-9646. [CrossRef] [PubMed]

103. Lai, C.K.; Jeng, K.S.; Machida, K.; Cheng, Y.S.; Lai, M.M. Hepatitis C virus NS3/4A protein interacts with ATM, impairs DNA repair and enhances sensitivity to ionizing radiation. Virology 2008, 370, 295-309. [CrossRef] [PubMed]

104. Xu, L.H.; Huang, M.; Fang, S.G.; Liu, D.X. Coronavirus infection induces DNA replication stress partly through interaction of its nonstructural protein 13 with the p125 subunit of DNA polymerase delta. J. Biol. Chem. 2011, 286, 39546-39559. [CrossRef] [PubMed]

105. Li, N.; Parrish, M.; Chan, T.K.; Yin, L.; Rai, P.; Yoshiyuki, Y.; Abolhassani, N.; Tan, K.B.; Kiraly, O.; Chow, V.T.; et al. Influenza infection induces host DNA damage and dynamic DNA damage responses during tissue regeneration. Cell Mol. Life Sci. 2015, 72, 2973-2988. [CrossRef] [PubMed]

106. Vijaya Lakshmi, A.N.; Ramana, M.V.; Vijayashree, B.; Ahuja, Y.R.; Sharma, G. Detection of influenza virus induced DNA damage by comet assay. Mutat. Res. 1999, 442, 53-58. [CrossRef]

107. Clavarino, G.; Claudio, N.; Couderc, T.; Dalet, A.; Judith, D.; Camosseto, V.; Schmidt, E.K.; Wenger, T.; Lecuit, M.; Gatti, E.; et al. Induction of GADD34 is necessary for dsRNA-dependent interferon-beta production and participates in the control of Chikungunya virus infection. PLoS Pathog. 2012, 8, e1002708. [CrossRef] [PubMed]

108. Nargi-Aizenman, J.L.; Simbulan-Rosenthal, C.M.; Kelly, T.A.; Smulson, M.E.; Griffin, D.E. Rapid activation of poly(ADP-ribose) polymerase contributes to Sindbis virus and staurosporine-induced apoptotic cell death. Virology 2002, 293, 164-171. [CrossRef] [PubMed]

109. Verbruggen, P.; Ruf, M.; Blakqori, G.; Overby, A.K.; Heidemann, M.; Eick, D.; Weber, F. Interferon antagonist NSs of La Crosse virus triggers a DNA damage response-like degradation of transcribing RNA polymerase II. J. Biol. Chem. 2011, 286, 3681-3692. [CrossRef] [PubMed]

110. Baer, A.; Austin, D.; Narayanan, A.; Popova, T.; Kainulainen, M.; Bailey, C.; Kashanchi, F.; Weber, F.; Kehn-Hall, K. Induction of DNA damage signaling upon Rift Valley fever virus infection results in cell cycle arrest and increased viral replication. J. Biol. Chem. 2012, 287, 7399-7410. [CrossRef] [PubMed]

111. Lin, P.Y.; Liu, H.J.; Chang, C.D.; Chang, C.I.; Hsu, J.L.; Liao, M.H.; Lee, J.W.; Shih, W.L. Avian reovirus S1133-induced DNA damage signaling and subsequent apoptosis in cultured cells and in chickens. Arch. Virol. 2011, 156, 1917-1929. [CrossRef] [PubMed]

112. Yang, Y.X.; Guen, V.; Richard, J.; Cohen, E.A.; Berthoux, L. Cell context-dependent involvement of ATR in early stages of retroviral replication. Virology 2010, 396, 272-279. [CrossRef] [PubMed]

113. Daniel, R.; Katz, R.A.; Skalka, A.M. A role for DNA-PK in retroviral DNA integration. Science 1999, 284, 644-647. [CrossRef] [PubMed]

114. Li, L.; Olvera, J.M.; Yoder, K.E.; Mitchell, R.S.; Butler, S.L.; Lieber, M.; Martin, S.L.; Bushman, F.D. Role of the non-homologous DNA end joining pathway in the early steps of retroviral infection. EMBO J. 2001, 20, 3272-3281. [CrossRef] [PubMed]

115. Jeanson, L.; Subra, F.; Vaganay, S.; Hervy, M.; Marangoni, E.; Bourhis, J.; Mouscadet, J.F. Effect of Ku80 depletion on the preintegrative steps of HIV-1 replication in human cells. Virology 2002, 300, 100-108. [CrossRef] [PubMed]

116. Lau, A.; Kanaar, R.; Jackson, S.P.; O'Connor, M.J. Suppression of retroviral infection by the RAD52 DNA repair protein. EMBO J. 2004, 23, 3421-3429. [CrossRef] [PubMed] 
117. Daniel, R.; Greger, J.G.; Katz, R.A.; Taganov, K.D.; Wu, X.; Kappes, J.C.; Skalka, A.M. Evidence that stable retroviral transduction and cell survival following DNA integration depend on components of the nonhomologous end joining repair pathway. J. Virol. 2004, 78, 8573-8581. [CrossRef] [PubMed]

118. Waninger, S.; Kuhen, K.; Hu, X.; Chatterton, J.E.; Wong-Staal, F.; Tang, H. Identification of cellular cofactors for human immunodeficiency virus replication via a ribozyme-based genomics approach. J. Virol. 2004, 78, 12829-12837. [CrossRef] [PubMed]

119. Baekelandt, V.; Claeys, A.; Cherepanov, P.; De Clercq, E.; de Strooper, B.; Nuttin, B.; Debyser, Z. DNA-Dependent protein kinase is not required for efficient lentivirus integration. J. Virol. 2000, 74, 11278-11285. [CrossRef] [PubMed]

120. Daniel, R.; Kao, G.; Taganov, K.; Greger, J.G.; Favorova, O.; Merkel, G.; Yen, T.J.; Katz, R.A.; Skalka, A.M. Evidence that the retroviral DNA integration process triggers an ATR-dependent DNA damage response. Proc. Natl. Acad. Sci. USA 2003, 100, 4778-4783. [CrossRef] [PubMed]

121. Daniel, R.; Katz, R.A.; Merkel, G.; Hittle, J.C.; Yen, T.J.; Skalka, A.M. Wortmannin potentiates integrase-mediated killing of lymphocytes and reduces the efficiency of stable transduction by retroviruses. Mol. Cell. Biol. 2001, 21, 1164-1172. [CrossRef] [PubMed]

122. Lau, A.; Swinbank, K.M.; Ahmed, P.S.; Taylor, D.L.; Jackson, S.P.; Smith, G.C.; O'Connor, M.J. Suppression of HIV-1 infection by a small molecule inhibitor of the ATM kinase. Nat. Cell Biol. 2005, 7, 493-500. [CrossRef] [PubMed]

123. Ariumi, Y.; Turelli, P.; Masutani, M.; Trono, D. DNA damage sensors ATM, ATR, DNA-PKcs, and PARP-1 are dispensable for human immunodeficiency virus type 1 integration. J. Virol. 2005, 79, 2973-2978. [CrossRef] [PubMed]

124. Dehart, J.L.; Andersen, J.L.; Zimmerman, E.S.; Ardon, O.; An, D.S.; Blackett, J.; Kim, B.; Planelles, V. The ataxia telangiectasia-mutated and Rad3-related protein is dispensable for retroviral integration. J. Virol. 2005, 79, 1389-1396. [CrossRef] [PubMed]

125. Bouchard, V.J.; Rouleau, M.; Poirier, G.G. PARP-1, a determinant of cell survival in response to DNA damage. Exp. Hematol. 2003, 31, 446-454. [CrossRef]

126. Gaken, J.A.; Tavassoli, M.; Gan, S.U.; Vallian, S.; Giddings, I.; Darling, D.C.; Galea-Lauri, J.; Thomas, M.G.; Abedi, H.; Schreiber, V.; et al. Efficient retroviral infection of mammalian cells is blocked by inhibition of poly(ADP-ribose) polymerase activity. J. Virol. 1996, 70, 3992-4000. [PubMed]

127. Ha, H.C.; Juluri, K.; Zhou, Y.; Leung, S.; Hermankova, M.; Snyder, S.H. Poly(ADP-ribose) polymerase-1 is required for efficient HIV-1 integration. Proc. Natl. Acad. Sci. USA 2001, 98, 3364-3368. [CrossRef] [PubMed]

128. Kameoka, M.; Nukuzuma, S.; Itaya, A.; Tanaka, Y.; Ota, K.; Inada, Y.; Ikuta, K.; Yoshihara, K. Poly(ADP-ribose)polymerase- 1 is required for integration of the human immunodeficiency virus type 1 genome near centromeric alphoid DNA in human and murine cells. Biochem. Biophys. Res. Commun. 2005, 334, 412-417. [CrossRef] [PubMed]

129. Siva, A.C.; Bushman, F. Poly(ADP-ribose) polymerase 1 is not strictly required for infection of murine cells by retroviruses. J. Virol. 2002, 76, 11904-11910. [CrossRef] [PubMed]

130. Boehler, C.; Gauthier, L.R.; Mortusewicz, O.; Biard, D.S.; Saliou, J.M.; Bresson, A.; Sanglier-Cianferani, S.; Smith, S.; Schreiber, V.; Boussin, F.; et al. Poly(ADP-ribose) polymerase 3 (PARP3), a newcomer in cellular response to DNA damage and mitotic progression. Proc. Natl. Acad. Sci. USA 2011, 108, 2783-2788. [CrossRef] [PubMed]

131. De Murcia, J.M.; Ricoul, M.; Tartier, L.; Niedergang, C.; Huber, A.; Dantzer, F.; Schreiber, V.; Ame, J.C.; Dierich, A.; LeMeur, M.; et al. Functional interaction between PARP-1 and PARP-2 in chromosome stability and embryonic development in mouse. EMBO J. 2003, 22, 2255-2263. [CrossRef] [PubMed]

132. Bueno, M.T.; Reyes, D.; Valdes, L.; Saheba, A.; Urias, E.; Mendoza, C.; Fregoso, O.I.; Llano, M. Poly(ADP-ribose) polymerase 1 promotes transcriptional repression of integrated retroviruses. J. Virol. 2013, 87, 2496-2507. [CrossRef] [PubMed]

133. Cappelli, E.; Rossi, O.; Chessa, L.; Frosina, G. Efficient DNA base excision repair in ataxia telangiectasia cells. Eur. J. Biochem. 2000, 267, 6883-6887. [CrossRef] [PubMed]

134. Espeseth, A.S.; Fishel, R.; Hazuda, D.; Huang, Q.; Xu, M.; Yoder, K.; Zhou, H. siRNA screening of a targeted library of DNA repair factors in HIV infection reveals a role for base excision repair in HIV integration. PLoS ONE 2011, 6, e17612. [CrossRef] [PubMed] 
135. Yoder, K.E.; Espeseth, A.; Wang, X.H.; Fang, Q.; Russo, M.T.; Lloyd, R.S.; Hazuda, D.; Sobol, R.W.; Fishel, R. The base excision repair pathway is required for efficient lentivirus integration. PLoS ONE 2011, 6, e17862. [CrossRef] [PubMed]

136. Smith, J.A.; Wang, F.X.; Zhang, H.; Wu, K.J.; Williams, K.J.; Daniel, R. Evidence that the Nijmegen breakage syndrome protein, an early sensor of double-strand DNA breaks (DSB), is involved in HIV-1 post-integration repair by recruiting the ataxia telangiectasia-mutated kinase in a process similar to, but distinct from, cellular DSB repair. Virol. J. 2008. [CrossRef]

137. Tang, H.; Kuhen, K.L.; Wong-Staal, F. Lentivirus replication and regulation. Annu. Rev. Genet. 1999, 33, 133-170. [CrossRef] [PubMed]

138. Kogan, M.; Rappaport, J. HIV-1 accessory protein Vpr: Relevance in the pathogenesis of HIV and potential for therapeutic intervention. Retrovirology 2011. [CrossRef] [PubMed]

139. Jowett, J.B.; Planelles, V.; Poon, B.; Shah, N.P.; Chen, M.L.; Chen, I.S. The human immunodeficiency virus type 1 Vpr gene arrests infected T cells in the G2 + M phase of the cell cycle. J. Virol. 1995, 69, 6304-6313. [PubMed]

140. He, J.; Choe, S.; Walker, R.; Di Marzio, P.; Morgan, D.O.; Landau, N.R. Human immunodeficiency virus type 1 viral protein $\mathrm{R}(\mathrm{Vpr})$ arrests cells in the G2 phase of the cell cycle by inhibiting p34cdc2 activity. J. Virol. 1995, 69, 6705-6711. [PubMed]

141. Rogel, M.E.; Wu, L.I.; Emerman, M. The human immunodeficiency virus type 1 Vpr gene prevents cell proliferation during chronic infection. J. Virol. 1995, 69, 882-888. [PubMed]

142. Re, F.; Braaten, D.; Franke, E.K.; Luban, J. Human immunodeficiency virus type 1 Vpr arrests the cell cycle in G2 by inhibiting the activation of p34cdc2-cyclin B. J. Virol. 1995, 69, 6859-6864. [PubMed]

143. Stewart, S.A.; Poon, B.; Jowett, J.B.; Chen, I.S. Human immunodeficiency virus type 1 Vpr induces apoptosis following cell cycle arrest. J. Virol. 1997, 71, 5579-5592. [PubMed]

144. Bartz, S.R.; Rogel, M.E.; Emerman, M. Human immunodeficiency virus type 1 cell cycle control: Vpr is cytostatic and mediates G2 accumulation by a mechanism which differs from DNA damage checkpoint control. J. Virol. 1996, 70, 2324-2331. [PubMed]

145. Shostak, L.D.; Ludlow, J.; Fisk, J.; Pursell, S.; Rimel, B.J.; Nguyen, D.; Rosenblatt, J.D.; Planelles, V. Roles of p53 and caspases in the induction of cell cycle arrest and apoptosis by HIV-1 Vpr. Exp. Cell Res. 1999, 251, 156-165. [CrossRef] [PubMed]

146. Zhu, Y.; Gelbard, H.A.; Roshal, M.; Pursell, S.; Jamieson, B.D.; Planelles, V. Comparison of cell cycle arrest, transactivation, and apoptosis induced by the simian immunodeficiency virus SIVagm and human immunodeficiency virus type 1 vpr genes. J. Virol. 2001, 75, 3791-3801. [CrossRef] [PubMed]

147. Groschel, B.; Bushman, F. Cell cycle arrest in G2/M promotes early steps of infection by human immunodeficiency virus. J. Virol. 2005, 79, 5695-5704. [CrossRef] [PubMed]

148. Goh, W.C.; Rogel, M.E.; Kinsey, C.M.; Michael, S.F.; Fultz, P.N.; Nowak, M.A.; Hahn, B.H.; Emerman, M. HIV-1 Vpr increases viral expression by manipulation of the cell cycle: A mechanism for selection of $\mathrm{Vpr}$ in vivo. Nat. Med. 1998, 4, 65-71. [CrossRef] [PubMed]

149. Brasey, A.; Lopez-Lastra, M.; Ohlmann, T.; Beerens, N.; Berkhout, B.; Darlix, J.L.; Sonenberg, N. The leader of human immunodeficiency virus type 1 genomic RNA harbors an internal ribosome entry segment that is active during the G2/M phase of the cell cycle. J. Virol. 2003, 77, 3939-3949. [CrossRef] [PubMed]

150. Nakai-Murakami, C.; Shimura, M.; Kinomoto, M.; Takizawa, Y.; Tokunaga, K.; Taguchi, T.; Hoshino, S.; Miyagawa, K.; Sata, T.; Kurumizaka, H.; et al. HIV-1 Vpr induces ATM-dependent cellular signal with enhanced homologous recombination. Oncogene 2007, 26, 477-486. [CrossRef] [PubMed]

151. Andersen, J.L.; Zimmerman, E.S.; DeHart, J.L.; Murala, S.; Ardon, O.; Blackett, J.; Chen, J.; Planelles, V. ATR and GADD45alpha mediate HIV-1 Vpr-induced apoptosis. Cell Death Differ. 2005, 12, 326-334. [CrossRef] [PubMed]

152. Roshal, M.; Kim, B.; Zhu, Y.; Nghiem, P.; Planelles, V. Activation of the ATR-mediated DNA damage response by the HIV-1 viral protein R. J. Biol. Chem. 2003, 278, 25879-25886. [CrossRef] [PubMed]

153. Zimmerman, E.S.; Chen, J.; Andersen, J.L.; Ardon, O.; Dehart, J.L.; Blackett, J.; Choudhary, S.K.; Camerini, D.; Nghiem, P.; Planelles, V. Human immunodeficiency virus type 1 Vpr-mediated G2 arrest requires Rad17 and Hus1 and induces nuclear BRCA1 and gamma-H2AX focus formation. Mol. Cell. Biol. 2004, 24, 9286-9294. [CrossRef] [PubMed] 
154. Li, G.; Elder, R.T.; Qin, K.; Park, H.U.; Liang, D.; Zhao, R.Y. Phosphatase type 2A-dependent and -independent pathways for ATR phosphorylation of Chk1. J. Biol. Chem. 2007, 282, 7287-7298. [CrossRef] [PubMed]

155. Li, G.; Park, H.U.; Liang, D.; Zhao, R.Y. Cell cycle G2/M arrest through an S phase-dependent mechanism by HIV-1 viral protein R. Retrovirology 2010. [CrossRef] [PubMed]

156. Scheffner, M.; Huibregtse, J.M.; Vierstra, R.D.; Howley, P.M. The HPV-16 E6 and E6-AP complex functions as a ubiquitin-protein ligase in the ubiquitination of p53. Cell 1993, 75, 495-505. [CrossRef]

157. Leupin, O.; Bontron, S.; Schaeffer, C.; Strubin, M. Hepatitis B virus X protein stimulates viral genome replication via a DDB1-dependent pathway distinct from that leading to cell death. J. Virol. 2005, 79, 4238-4245. [CrossRef] [PubMed]

158. Ulane, C.M.; Horvath, C.M. Paramyxoviruses SV5 and HPIV2 assemble STAT protein ubiquitin ligase complexes from cellular components. Virology 2002, 304, 160-166. [CrossRef] [PubMed]

159. Belzile, J.P.; Duisit, G.; Rougeau, N.; Mercier, J.; Finzi, A.; Cohen, E.A. HIV-1 Vpr-mediated G2 arrest involves the DDB1-CUL4AVPRBP E3 ubiquitin ligase. PLoS Pathog. 2007, 3, e85. [CrossRef] [PubMed]

160. DeHart, J.L.; Zimmerman, E.S.; Ardon, O.; Monteiro-Filho, C.M.; Arganaraz, E.R.; Planelles, V. HIV-1 Vpr activates the G2 checkpoint through manipulation of the ubiquitin proteasome system. Virol. J. 2007, 4, 57. [CrossRef] [PubMed]

161. Belzile, J.P.; Richard, J.; Rougeau, N.; Xiao, Y.; Cohen, E.A. HIV-1 Vpr induces the K48-linked polyubiquitination and proteasomal degradation of target cellular proteins to activate ATR and promote G2 arrest. J. Virol. 2010, 84, 3320-3330. [CrossRef] [PubMed]

162. Deshmane, S.L.; Mukerjee, R.; Fan, S.; del Valle, L.; Michiels, C.; Sweet, T.; Rom, I.; Khalili, K.; Rappaport, J.; Amini, S.; et al. Activation of the oxidative stress pathway by HIV-1 Vpr leads to induction of hypoxia-inducible factor 1alpha expression. J. Biol. Chem. 2009, 284, 11364-11373. [CrossRef] [PubMed]

163. Stromajer-Racz, T.; Gazdag, Z.; Belagyi, J.; Vagvolgyi, C.; Zhao, R.Y.; Pesti, M. Oxidative stress induced by HIV-1 F34IVpr in Schizosaccharomyces pombe is one of its multiple functions. Exp. Mol. Pathol. 2010, 88, 38-44. [CrossRef] [PubMed]

164. Muthumani, K.; Zhang, D.; Hwang, D.S.; Kudchodkar, S.; Dayes, N.S.; Desai, B.M.; Malik, A.S.; Yang, J.S.; Chattergoon, M.A.; Maguire, H.C., Jr.; et al. Adenovirus encoding HIV-1 Vpr activates caspase 9 and induces apoptotic cell death in both p53 positive and negative human tumor cell lines. Oncogene 2002, 21, 4613-4625. [CrossRef] [PubMed]

165. Shimura, M.; Onozuka, Y.; Yamaguchi, T.; Hatake, K.; Takaku, F.; Ishizaka, Y. Micronuclei formation with chromosome breaks and gene amplification caused by Vpr, an accessory gene of human immunodeficiency virus. Cancer Res. 1999, 59, 2259-2264. [PubMed]

166. Grassmann, R.; Dengler, C.; Muller-Fleckenstein, I.; Fleckenstein, B.; McGuire, K.; Dokhelar, M.C.; Sodroski, J.G.; Haseltine, W.A. Transformation to continuous growth of primary human T lymphocytes by human T-cell leukemia virus type I X-region genes transduced by a Herpesvirus saimiri vector. Proc. Natl. Acad. Sci. USA 1989, 86, 3351-3355. [CrossRef] [PubMed]

167. Currer, R.; Van Duyne, R.; Jaworski, E.; Guendel, I.; Sampey, G.; Das, R.; Narayanan, A.; Kashanchi, F. HTLV tax: A fascinating multifunctional co-regulator of viral and cellular pathways. Front. Microbiol. 2012, 3, 406. [CrossRef] [PubMed]

168. Takahashi, M.; Higuchi, M.; Makokha, G.N.; Matsuki, H.; Yoshita, M.; Tanaka, Y.; Fujii, M. HTLV-1 Tax oncoprotein stimulates ROS production and apoptosis in T cells by interacting with USP10. Blood 2013, 122, 715-725. [CrossRef] [PubMed]

169. Los, M.; Khazaie, K.; Schulze-Osthoff, K.; Baeuerle, P.A.; Schirrmacher, V.; Chlichlia, K. Human T cell leukemia virus-I (HTLV-I) Tax-mediated apoptosis in activated T cells requires an enhanced intracellular prooxidant state. J. Immunol. 1998, 161, 3050-3055. [PubMed]

170. Kinjo, T.; Ham-Terhune, J.; Peloponese, J.M., Jr.; Jeang, K.T. Induction of reactive oxygen species by human T-cell leukemia virus type 1 tax correlates with DNA damage and expression of cellular senescence marker. J. Virol. 2010, 84, 5431-5437. [CrossRef] [PubMed]

171. Chaib-Mezrag, H.; Lemacon, D.; Fontaine, H.; Bellon, M.; Bai, X.T.; Drac, M.; Coquelle, A.; Nicot, C. Tax impairs DNA replication forks and increases DNA breaks in specific oncogenic genome regions. Mol. Cancer 2014. [CrossRef] [PubMed]

172. Jeang, K.T.; Widen, S.G.; Semmes, O.J.; Wilson, S.H. HTLV-I trans-activator protein, tax, is a trans-repressor of the human beta-polymerase gene. Science 1990, 247, 1082-1084. [CrossRef] [PubMed] 
173. Dayaram, T.; Lemoine, F.J.; Donehower, L.A.; Marriott, S.J. Activation of WIP1 phosphatase by HTLV-1 Tax mitigates the cellular response to DNA damage. PLoS ONE 2013, 8, e55989. [CrossRef] [PubMed]

174. Boxus, M.; Twizere, J.C.; Legros, S.; Kettmann, R.; Willems, L. Interaction of HTLV-1 Tax with minichromosome maintenance proteins accelerates the replication timing program. Blood 2012, 119, 151-160. [CrossRef] [PubMed]

175. Park, H.U.; Jeong, J.H.; Chung, J.H.; Brady, J.N. Human T-cell leukemia virus type 1 Tax interacts with Chk1 and attenuates DNA-damage induced G2 arrest mediated by Chk1. Oncogene 2004, 23, 4966-4974. [CrossRef] [PubMed]

176. Gupta, S.K.; Guo, X.; Durkin, S.S.; Fryrear, K.F.; Ward, M.D.; Semmes, O.J. Human T-cell leukemia virus type 1 Tax oncoprotein prevents DNA damage-induced chromatin egress of hyperphosphorylated Chk2. J. Biol. Chem. 2007, 282, 29431-29440. [CrossRef] [PubMed]

177. Haoudi, A.; Semmes, O.J. The HTLV-1 tax oncoprotein attenuates DNA damage induced G1 arrest and enhances apoptosis in p53 null cells. Virology 2003, 305, 229-239. [CrossRef] [PubMed]

178. Durkin, S.S.; Guo, X.; Fryrear, K.A.; Mihaylova, V.T.; Gupta, S.K.; Belgnaoui, S.M.; Haoudi, A.; Kupfer, G.M.; Semmes, O.J. HTLV-1 Tax oncoprotein subverts the cellular DNA damage response via binding to DNA-dependent protein kinase. J. Biol. Chem. 2008, 283, 36311-36320. [CrossRef] [PubMed]

179. Joyce, M.A.; Tyrrell, D.L. The cell biology of hepatitis C virus. Microbes Infect. 2010, 12, 263-271. [CrossRef] [PubMed]

180. Sharma, S.D. Hepatitis C virus: Molecular biology \& current therapeutic options. Indian J. Med. Res. 2010, 131, 17-34. [PubMed]

181. Van Pelt, J.F.; Severi, T.; Crabbe, T.; Eetveldt, A.V.; Verslype, C.; Roskams, T.; Fevery, J. Expression of hepatitis C virus core protein impairs DNA repair in human hepatoma cells. Cancer Lett. 2004, 209, 197-205. [CrossRef] [PubMed]

182. Zekri, A.R.; Sabry, G.M.; Bahnassy, A.A.; Shalaby, K.A.; Abdel-Wahabh, S.A.; Zakaria, S. Mismatch repair genes (hMLH1, hPMS1, hPMS2, GTBP/hMSH6, hMSH2) in the pathogenesis of hepatocellular carcinoma. World J. Gastroenterol. 2005, 11, 3020-3026. [CrossRef] [PubMed]

183. Cooke, M.S.; Evans, M.D.; Dizdaroglu, M.; Lunec, J. Oxidative DNA damage: Mechanisms, mutation, and disease. FASEB J. 2003, 17, 1195-1214. [CrossRef] [PubMed]

184. Pal, S.; Polyak, S.J.; Bano, N.; Qiu, W.C.; Carithers, R.L.; Shuhart, M.; Gretch, D.R.; Das, A. Hepatitis C virus induces oxidative stress, DNA damage and modulates the DNA repair enzyme NEIL1. J. Gastroenterol. Hepatol. 2010, 25, 627-634. [CrossRef] [PubMed]

185. Higgs, M.R.; Lerat, H.; Pawlotsky, J.M. Downregulation of Gadd45beta expression by hepatitis C virus leads to defective cell cycle arrest. Cancer Res. 2010, 70, 4901-4911. [CrossRef] [PubMed]

186. Bittar, C.; Shrivastava, S.; Bhanja Chowdhury, J.; Rahal, P.; Ray, R.B. Hepatitis C virus NS2 protein inhibits DNA damage pathway by sequestering p53 to the cytoplasm. PLoS ONE 2013, 8, e62581. [CrossRef] [PubMed]

187. Cook, J.K.; Jackwood, M.; Jones, R.C. The long view: 40 years of infectious bronchitis research. Avian Pathol. 2012, 41, 239-250. [CrossRef] [PubMed]

188. Brian, D.A.; Baric, R.S. Coronavirus genome structure and replication. Curr. Top. Microbiol. Immunol. 2005, 287, 1-30. [PubMed]

189. Dove, B.; Brooks, G.; Bicknell, K.; Wurm, T.; Hiscox, J.A. Cell cycle perturbations induced by infection with the coronavirus infectious bronchitis virus and their effect on virus replication. J. Virol. 2006, 80, 4147-4156. [CrossRef] [PubMed]

190. Li, F.Q.; Tam, J.P.; Liu, D.X. Cell cycle arrest and apoptosis induced by the coronavirus infectious bronchitis virus in the absence of p53. Virology 2007, 365, 435-445. [CrossRef] [PubMed]

191. Xu, L.; Khadijah, S.; Fang, S.; Wang, L.; Tay, F.P.; Liu, D.X. The cellular RNA helicase DDX1 interacts with coronavirus nonstructural protein 14 and enhances viral replication. J. Virol. 2010, 84, 8571-8583. [CrossRef] [PubMed]

192. Samji, T. Influenza A: Understanding the viral life cycle. Yale J. Biol. Med. 2009, 82, 153-159. [PubMed]

193. Schrauwen, E.J.; Fouchier, R.A. Host adaptation and transmission of influenza A viruses in mammals. Emerg. Microbes Infect. 2014, 3, e9. [CrossRef] [PubMed]

194. Khanna, M.; Ray, A.; Rawall, S.; Chandna, S.; Kumar, B.; Vijayan, V.K. Detection of influenza virus induced ultrastructural changes and DNA damage. Indian J. Virol. 2010, 21, 50-55. [CrossRef] [PubMed] 
195. Reshi, M.L.; Su, Y.C.; Hong, J.R. RNA viruses: ROS-mediated cell death. Int. J. Cell Biol. 2014, $2014,467452$. [CrossRef] [PubMed]

196. Jeggo, P.A.; Lobrich, M. DNA double-strand breaks: Their cellular and clinical impact? Oncogene 2007, 26, 7717-7719. [CrossRef] [PubMed]

197. Col, E.; Caron, C.; Chable-Bessia, C.; Legube, G.; Gazzeri, S.; Komatsu, Y.; Yoshida, M.; Benkirane, M.; Trouche, D.; Khochbin, S. HIV-1 Tat targets Tip60 to impair the apoptotic cell response to genotoxic stresses. EMBO J. 2005, 24, 2634-2645. [CrossRef] [PubMed]

198. Sun, Y.; Huang, Y.C.; Xu, Q.Z.; Wang, H.P.; Bai, B.; Sui, J.L.; Zhou, P.K. HIV-1 Tat depresses DNA-PK(CS) expression and DNA repair, and sensitizes cells to ionizing radiation. Int. J. Radiat. Oncol. Biol. Phys. 2006, 65, 842-850. [CrossRef] [PubMed]

199. Zhang, S.M.; Zhang, H.; Yang, T.Y.; Ying, T.Y.; Yang, P.X.; Liu, X.D.; Tang, S.J.; Zhou, P.K. Interaction between HIV-1 Tat and DNA-PKcs modulates HIV transcription and class switch recombination. Int. J. Biol. Sci. 2014, 10, 1138-1149. [CrossRef] [PubMed]

(C) 2016 by the authors; licensee MDPI, Basel, Switzerland. This article is an open access article distributed under the terms and conditions of the Creative Commons by Attribution (CC-BY) license (http://creativecommons.org/licenses/by/4.0/). 